\title{
UNSCREWING THE INSCRUTABLE: THE UK BRIBERY ACT 2010
}

\author{
Bruce W. Bean \& Emma H. MacGuidwin*
}

\section{INTRODUCTION}

On December 17, 1997 the United Kingdom, a founding member of the Organization for Economic Cooperation and Development ("OECD"), signed the OECD Convention on Combating Bribery of Foreign Public Officials in International Business Transactions (the "OECD Convention" or "Convention"). ${ }^{1}$ This Convention obligates signatory states to criminalize bribery of foreign public officials by those seeking to obtain or retain business. The UK Bribery Act 2010 (the "Bribery Act" or the "Act"), ${ }^{2}$ enacted after more than a decade of debate, delay, and desultory deliberation, is the culmination of the United Kingdom's extraordinarily extended effort to update its antiquated corruption legislation and thus comply with its obligations under the OECD Convention.

The Bribery Act is a wholesale revision of all United Kingdom domestic bribery and corruption statutes, some dating from the nineteenth century. The Act applies to both domestic and foreign bribery. In this article we review the operative provisions of the Bribery Act and then focus on a shocking new crime: the failure of a commercial enterprise to prevent a bribe. This crime, which requires no criminal intent and no knowledge of the offending bribe, will ensnare many non-UK businesses involved in cross border transactions. This is so because the Bribery Act contains an expansive concept of what may be deemed a bribe under the Act and because the jurisdictional reach of the Act is unparalleled. The Act also provides that the offending bribe need not be committed by an employee of the-company. Any "associated person" may trigger the-strict liability crime

* Professor Bruce W. Bean teaches Business Enterprises and conducts the Global Law Colloquium at Michigan State University College of Law. He also coaches the Jessup International Moot Court Competition Team and is Faculty Advisor to the Michigan State University International Law Review. Earlier, Professor Bean had practiced corporate law for 30 years in New York, Los Angeles and Moscow. He is a graduate of Columbia Law School and clerked for Judge Leonard P. Moore on the U.S. Second Circuit Court of Appeals.

Emma H. MacGuidwin is a 2008 summa cum laude graduate of Michigan State University College of Law, where she served as Senior Articles Editor of the Law Review. She is a former law clerk to the Honorable Russell G. Vineyard, United States Magistrate Judge for the Northern District of Georgia.

1. OECD Convention on Combating Bribery of Foreign Public Officials in International Business Transactions, Dec. 17, 1997, available at http://www.oecd.org/ dataoecd/4/18/38028044.pdf [hereinafter OECD Convention].

2. Bribery Act, 2010, c.23, (U.K.) [hereinafter Bribery Act] 
of "failing to prevent bribery." The sole defense companies have to this crime is the nigh impossible task defense of demonstrating that the company had "adequate procedures" in place to prevent such bribery. Moreover, since the Act characterizes small facilitation payments, currently made all over the world in the ordinary course of traveling or conducting business, as "bribes", business as now conducted may have already triggered the Bribery Act's strict liability crime of failing to prevent bribery. Furthermore, this will be the case even for a non-UK business if it is found to be "carry[ing] on a business, or part of a business, in any part of the United Kingdom[.]" ${ }^{3}$ The surprising hypocrisy of Parliament criminalizing facilitation payments and, in certain instances, hospitality expenditures, while acknowledging that these are daily occurrences by both UK and non-UK companies, seems inexplicable. It is certainly indefensible.

Part I outlines the United Kingdom's leisurely pace of bringing its laws into compliance with the OECD Convention - a process that began on December 17, 1997 and was completed more than thirteen years later on July 1, 2011, when the Bribery Act finally became effective. Part II analyzes three offenses created by the Bribery Act - bribing another person, ${ }^{4}$ requesting or agreeing to receive a bribe, ${ }^{5}$ and bribery of a foreign public official. ${ }^{6}$ Part III explores what in our view is the most egregious aspect of the Bribery Act, the strict liability corporate crime of failing to prevent bribery, ${ }^{7}$ a crime that requires no mens rea and triggers unlimited fines. Parts I to III of this article draw on language from our previous article, Expansive Reach - Useless Guidance: An Introduction to the UK Bribery Act $2010 .^{8}$

Part IV probes the expansive scope of what is deemed a "bribe" under the Bribery Act. Once a bribe is alleged, a non-UK business doing only a part of its business in the United Kingdom will be guilty of failing to prevent a bribe even when such bribe was paid by a non-employee or other person over whom the now automatically guilty company has no operational control. In such a case, the sole defense available to the presumptively guilty company is to satisfy the burden of proving that, despite the occurrence of the alleged bribe that it failed to prevent, that company had in place adequate procedures designed to prevent that very bribe! We intend to show that the Bribery Act's operative provisions, particularly the strict liability provisions and the treatment of facilitation

3. $I d . \S 7(5)$.

4. Id. $\S 1$.

5. Id. $\S 2$.

6. $I d . \S 6(1)-(4)$.

7. $I d . \S 7$.

8. Bruce W. Bean \& Emma H. MacGuidwin, Expansive Reach - Useless Guidance: An Introduction to the UK Bribery Act 2010, 18 ILSA J. INT'L \& COMP. L. 325 (2012) [hereinafter Expansive Reach]. 
and hospitality payments, are unprecedented in their jurisdictional reach and cannot realistically be enforced. We conclude by commenting on concerns relating to the Bribery Act's violations of due process and the European Convention on Human Rights. The Bribery Act cannot hope to effect, in a legitimate way, Parliament's goal of ending bribery in the United Kingdom and elsewhere.

\section{With All Deliberate Delay: The SORDiD Saga of THE Ultimate BIRTH OF THE UK BRIBERY ACT}

This part outlines the genesis and development of global anti-bribery legislation, beginning with the history of the United States Foreign Corrupt Practices Act, the predecessor of all modern anti-bribery efforts. We then explore the background of the OECD Convention and the role it played in the development and enactment of the Bribery Act. We also trace the long and tortuous history of the United Kingdom's efforts to comply with the OECD Convention by finally enacting the Bribery Act after more than a decade of debate and delay by Parliament.

\section{A. The US Foreign Corrupt Practices Act}

The United States began the global campaign to eliminate bribery and corruption in international business transactions in 1977 with the enactment of the Foreign Corrupt Practices Act ("FCPA"). ${ }^{9}$ The FCPA, a curious artifact of the Watergate Scandal, ${ }^{10}$ has two operative provisions. The first is that businesses keep accurate books and records of their financial transactions. This provision is enforced by the Securities and Exchange Commission. " For this article, the more important FCPA provision is the

9. Foreign Corrupt Practices Act of 1977, Pub. L. No. 95-213, 91 Stat. 1494, as amended by Title V of the Omnibus Trade \& Competitiveness Act of 1988, Pub. L. No. 100418 , secs. 5001-03, 102 Stat. $1415,1415-25$ (codified as amended at 15. U.S.C. $\S \S$ $78 \mathrm{~m}$ (b)(2), 78m(b)(3), 78dd-1, 78dd-2, 78ff (1994)).

10. The Watergate investigation revealed corporate "slush funds" as the source of contributions to the committee to reelect President Nixon, as well as to make "questionable payments" overseas. This led to an investigation by the Securities and Exchange Commission, which ultimately led to enactment of the Foreign Corrupt Practices Act. A description of the genesis of the FCPA is found in an article by Stanley Sporkin, Head of Enforcement at the Securities and Exchange Commission at the time the FCPA was being drafted in the mid-1970's. See, Stanley Sporkin, The Worldwide Banning of Schmiergeld: $A$ Look at the Foreign Corrupt Practices Act on its Twentieth Birthday, 18 Nw. J. INT'L L. \& Bus. 269, 271 (1998).

11. U.S. DeP'T OF JUsTiCE, Foreign Corrupt Practices Act: An Overview, http://www.justice.gov/criminal/fraud/fcpa/ (last visited Mar. 4, 2013). CRIMINAL Division OF THE U.S. DEP'T. OF JUSTICE \& THE ENFORCEMENT DIVISION OF THE U.S. SEC, FCPA: A Resource Guide to the U.S. Foreign Corrupt Practices ACt 4 - 5 (Nov. 14, 2012), available at http://www.justice.gov/criminal/fraud/fcpa/guide.pdf (hereinafter RESOURCE 
prohibition against bribing foreign government officials to obtain or retain business. $^{12}$ This portion of the FCPA is enforced by the Department of Justice. $^{13}$

It is important to note that the FCPA was amended in 1988 to make explicit that the FCPA does not prohibit "grease" or "facilitation" payments. Such payments are excluded from the definition of bribe when they are not "corrupt," that is, when such payment is not intended to obtain or retain business but simply to secure a "routine governmental action," such as approvals, licenses, permits, and the like, that are not subject to a foreign government official's discretion. ${ }^{14}$ The 1988 amendments also included a direction from Congress to the Executive Branch to end the competitive disadvantage US companies believed that they faced when no other nation criminalized bribes to foreign officials by urging other nations to similarly outlaw overseas bribery. ${ }^{15}$ This latter requirement ultimately resulted in negotiation and approval of the OECD Convention.

\section{B. The OECD and Other Anti-Bribery Conventions}

In 1997, twenty years after the FCPA went into effect, OECD member nations completed preparation of the OECD Convention. The OECD Convention obligates parties to enact domestic legislation criminalizing bribery of foreign government officials. ${ }^{16}$ Subsequent to negotiation of the Convention, five other anti-bribery conventions have

GUIDE TO THE FCPA). The Bribery Act does not contain a requirement that a company maintain accurate books and records. Such a provision is contained in Part 15 of the UK Companies Act 2006, Section 386.

12. RESOURCE GUIDE TO THE FCPA, supra note 11 , at $4-5$.

13. Id.at 5 .

14. 15 U.S.C. $\S 78$ dd-1(b)-3(b) (1998); S. REP. No. 100-85, at 53 (1987); H.R. REP. No. $100-40$, pt. 2, at 77 (1987).

A "routine governmental action" is only ordinarily and commonly performed by a foreign official in obtaining permits, licenses, or other official documents to qualify a person to do business in a foreign country; processing governmental papers; providing police protection, mail pick-up and delivery, or scheduling inspections associated with contract performance or inspections related to transit of goods across country; or providing phone service, power and water supply, loading and unloading cargo, or protecting perishable products or commodities from deterioration. The term does not include any decision by a foreign official whether or on what terms to award new business to or to continue business with a particular firm. 15 U.S.C. $\S 78 \mathrm{dd}-1(\mathrm{f})(3)$.

15. See, e.g., James R. Hines, Jr., Forbidden Payment: Foreign bribery and American Business after 1977 (Nat'l Bureau of Econ. Research, Working Paper No. 5266, 1995).

16. OECD Convention, supra note 1 , at art. $1 \S 1$. "Each Party shall take such measures as may be necessary to establish that it is a criminal offence under its law for any person intentionally to offer, promise or give any undue pecuniary or other advantage, whether directly or through intermediaries, to a foreign public official, for that official or for a third party, in order that the official act or refrain from acting in relation to the performance of official duties, in order to obtain or retain business or other improper advantage in the conduct of international business." 
been negotiated, four of which are now in effect. The five are as follows:

- United Nations Convention Against Corruption, Oct. $31,2003 .^{17}$

- Council of Europe Civil Law Convention on Corruption, Nov. 4, 1999. ${ }^{18}$

- Council of Europe Criminal Law Convention, Jan. 27, 1999. ${ }^{19}$

- Council of Europe, Additional Protocol to the Criminal Law Convention on Corruption, May 15, $2003 .^{20}$

- Organization of American States, Inter-American Convention Against Corruption, Mar. 29, 1996; ${ }^{21}$ and

- African Union Convention on Preventing and Combating Corruption, July $11,2003 .^{22}$

The broadest in scope of these international expressions of disapproval of bribery and corruption is the United Nations Convention Against Corruption, which binds 140 states and has twenty additional nations currently dealing with ratification. ${ }^{23}$

\section{The Adequacy of Prior UK Corruption Legislation}

The United Kingdom is an original member of the OECD and was an initial signatory of the OECD Convention in December 1997. As noted, the Convention requires parties to enact domestic legislation to make it a crime to pay bribes overseas in pursuit of business. After signing the OECD Convention, the British government took the position that its existing domestic anti-bribery legislation satisfied this requirement. This existing

17. U.N. Convention Against Corruption, GA Res. 58/4 (Oct. 31, 2003), available at http://www.unodc.org/unodc/en/treaties/CAC/.

18. Council of Europe, Civil Law Convention on Corruption, Nov. 4, 1999, E.T.S. no. 174, available at http://conventions.coe.int/Treaty/en/Treaties/Html/174.htm.

19. Council of Europe, Criminal Law Convention on Corruption, Jan. 27, 1999, E.T.S. no. 173, available at http://conventions.coe.int/Treaty/en/Treaties/Html/173.htm

20. Council of Europe, Additional Protocol to the Criminal Law Convention on Corruption, May 15, 2003, E.T.S. No. 173, available at http://conventions.coe.int/Treaty/en/ Treaties/Html/191.htm.

21. Organization of American States, Inter-American Convention against Corruption, Mar. 29, 1996, 35 I.L.M. 724, available at http://www.oas.org/juridico/english/treaties/b58.html.

22. African Union Convention on Preventing and Combating Cormuption, July 11, 2003, 43 1.L.M. 5, available at http://www.africa-union.org/root/au/documents/treaties/treaties.htm. 23 See United Nations Convention Against Corruption: UNCAC Signature and Ratification Status as of 09 November 2012, United Nations Office on Drugs and CRime, http://www.unodc.org/unodc/en/treaties/CAC/signatories.html (last visited Mar. 4, 2013). 
legislation included: the Public Bodies Corrupt Practices Act $1889{ }^{24}$ the Prevention of Corruption Act $1906,{ }^{25}$ and the Prevention of Corruption Act $1916^{26}$ (collectively, the "Prevention of Corruption Acts 1889-1916"). ${ }^{27}$ Notwithstanding this official position, at the time of signing the OECD Convention others disagreed, observing that the Prevention of Corruption Acts 1889-1916 did not adequately address overseas bribery, since there had never been such a prosecution by the United Kingdom. ${ }^{28}$ Indeed, until 1988 , bribes paid overseas were tax deductible in the United Kingdom. ${ }^{29}$ One official entity with special expertise in this area, the UK Law Commission, an independent body that periodically reviews the laws of England and Wales, ${ }^{30}$ flatly contradicted the government position by declaring immediately after the OECD Convention had been signed: "Under the present law, the English courts do not have jurisdiction to try a criminal offence unless the last act or event necessary for its completion occurs within the jurisdiction." ${ }^{31}$ Very clearly, however, the Bribery Act criminalizes acts of companies, even non-UK registered companies, which take place entirely outside the United Kingdom.

The OECD has established a Working Group to periodically monitor compliance with the mandates of the OECD Convention by nations that have signed the Convention. ${ }^{32}$ Each time the Working Group addressed UK compliance, it found it to be lacking. In 2008 the Working Group formally reported:

Overall, the Group is disappointed and seriously concerned with the unsatisfactory implementation of the Convention by the UK. The Working Group is particularly concerned that the UK's continued failure to address deficiencies in its

24. Public Bodies Corrupt Practices Act, 1889, 52 \& 53 Vict., c. 69 (U.K.).

25. Prevention of Corruption Act, 1906, 6 Edw. 7, c. 34 (U.K.).

26. Prevention of Corruption Act 1916, 6 \& 7 Geo. 5 , c. 64 (U.K.).

27. Public Bodies Corrupt Practices Act 1889 ("the 1889 Act") is concerned only with corruption in public bodies, while the Prevention of Corruption Act 1906 ("the 1906 Act") extends the law of corruption to all agents. The Prevention of Corruption Act 1916 ("the 1916 Act") applies only to persons "in the employment of [Her] Majesty or any Government Department or a public body." The LAw Commission, Legislating the Criminal Code: Corruption (LC248) 13 - 15 (Mar. 3, 1998) [hereinafter LEGISLATING THE CRIMINAL CODE: CORRUPTION] .

28. Id. at 24.

29. Such deductions were eliminated in 1988. Income and Corporation Taxes Act, 1988, c. 1 (U.K.).

30. The Law Commissions Act, 1965, c. 22 (U.K.).

31. Legislating THE Criminal CODE: CORRUPTION, supra note 27, at 103.

32. Bribery in International Business: OECD Working Group on Bribery-Annual Report, OECD: BETTER POLICIES FOR BETTER LIVES, http://www.oecd.org/daf/ briberyininternationalbusiness/oecdworkinggrouponbribery-annualreport.htm (last visited Mar. 4, 2013). 
laws on bribery of foreign public officials and on corporate liability for foreign bribery has hindered investigations. The Working Group reiterates its previous 2003, 2005 and 2007 recommendations that the UK enact new foreign bribery legislation at the earliest possible date. ${ }^{33}$

\section{Background on Revision of UK Corruption Laws}

In 1995, two years prior to completing negotiations for the OECD Convention, the UK Parliament convened a Committee on Standards in Public Life to address allegations that public officials in England operated in 'a pervasive atmosphere of 'sleaze', in which sexual, financial and governmental misconduct were indifferently linked." ${ }^{34}$ Referring to opinion polling conducted in 1985 and 1994, the Committee noted that "comparing 1985 with 1994, suggests that the level of public distrust of, and alienation from, [Members of Parliament], already high 10 years ago, has grown substantially since." ${ }^{\text {,35 }}$ The report of its findings, known as the Nolan Report, recommended a reconsideration of the three corruption laws constituting the "Prevention of Corruption Acts 1889-1916." Parliamentary Select Committee on Standards in Public Life then reviewed the Nolan Report and confirmed the need to replace the century-old bribery acts, which had previously been called for nearly two decades earlier in the Salmon Report. ${ }^{37}$ The UK government then called upon the Law

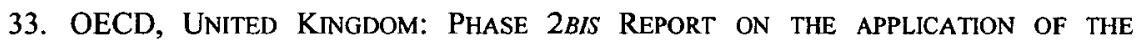
CONVENTION ON COMBATING BRIBERY OF FOREIGN PUBLIC OFFICIALS IN INTERNATIONAL BUSINESS TRANSACTIONS AND THE 1997 RECOMMENDATION ON COMBATING BRIBERY IN INTERNATIONAL BUSINESS TRANSACTIONS 4 (2008), available at http://www.oecd.org/ dataoecd/23/20/41515077.pdf.

34. Committee on Standards in Public Life, Standards in Public Life, 1995, ๆ 10 at 106 (U.K.).

35. Id., I 16 at 107.

36 See Home OfFice, The Prevention of Corruption, Consolidation and Amendment of THE PreVEntion of CoRruption ACTS 1889-1916: A GovernMENT STATEMENT, June 1997, available at http://www.publications.parliament.UK/pa/jt199899/jtselect/jtpriv/43/ 8012002.htm; see also THE LAW COMMISSION, REFORMING BRIBERY (LC 313) 12(2008-9) available at $\mathrm{http}: / /$ lawcommission.justice.gov.UK/docs/cp185_Reforming_Bribery_report.pdf [hereinafter LAW COMMISSION, REFORMING BRIBERY 2008].

37. "The Salmon Commission in 1976 recommended that such doubt should be resolved by legislation, but this has not been acted upon. We believe that it would be unsatisfactory to leave this issue outstanding when other aspects of the law of Parliament relating to conduct are being clarified. We recommend that the Government should now take steps to clarify the law relating to the bribery of or the receipt of a bribe by a Member of Parliament. This could usefully be combined with the consolidation of the statute law on bribery which Salmon also recommended, which the government accepted, but which has not been done. This might be a task which the Law Commission could take forward." COMMITTEE ON STANDARDS IN Public Life, Standards IN PUblic Life, 1995, ๆ 104 at 43 (U.K.). 
Commission to reconsider these laws. ${ }^{38}$

In March 1998, the Law Commission published an extensive report, "Legislating the Criminal Code: Corruption,"39 which included a draft Corruption Bill. The Report was "welcomed" by the Government. ${ }^{40} \mathrm{~A}$ working group within the Government, established to draft a suitable law, apparently "worked" for five years to produce a draft of the bill, which "largely reflected the draft Bill appended to the [1998 Law] Commission's report." ${ }^{41}$ Although the Law Commission's analysis had been before Parliament and the public since March 1998, the reaction of a Parliamentary Joint Committee to the 2003 draft law was adverse. ${ }^{42}$ At the end of 2003, the Government issued a report challenging some of the Joint Committee's proposed amendments to the 2003 draft Corruption Bill and setting forth perceived shortcomings in the Joint Committee's adverse findings. ${ }^{43}$

In December 2005, two years after the Joint Committee Report and eleven years after the United Kingdom signed the OECD Convention, the Government, through the Home Office, sought public comment (referred to in the United Kingdom as a "consultation") on the Prevention of Corruption Acts $1889-1916{ }^{44}$ By March 2007, thirty years after the FCPA was enacted, the results of this consultation were made public. ${ }^{45}$ The bottom line of the consultation was simply that there was no consensus on the approach a new act should take. ${ }^{46}$

A significant development during this period, and one which appears to have moved the government and Parliament to finally take definitive action, was the BAE Systems plc ("BAE") bribery scandal. In December 2004, BAE, the largest defense contractor in the United Kingdom, first publicly confirmed that it was being investigated by the Serious Fraud Office (the "SFO") ${ }^{47}$ for bribing public officials of Saudi Arabia in

38. See, e.g., Bribery Bill, 2010, H.L. Bill [69] (Eng.); Ministry of Justice, Bribery: Draft Legislation, Explanatory Notes 1 Tा 5-6.

39. Legislating the Criminal Code: Corruption, supra note 27, 1998, The Law Commission 248 (U.K.).

40. Monty RaphaEl, Blackstone’s Guide to the Bribery ACt , $\mid$ 2.63, at 23 (2010).

41. Id.

42. Joint Committee on the Draft Corruption Bill, Draft Corruption Bill REPORT AND EVIDENCE, 2002-3, H.L. 157, H.C. 705 (U.K.).

43. HOME DePaRTMENT, THE GOV'T RePLy to THE REPORT FROM THE JOINT COMM. ON THE DRAFT CORRUPTION BILL, 2002-3, H.L. 157, H.C. 705 (U.K.).

44. Home OfFice, Bribery: Reform of the Prevention of Corruption acts and SFO POWERS IN CASES OF BRIBERY OF Foreign OfFicials: a CONSUltation Paper (Dec. 2005), available at http://www.docstoc.com/docs/71020623/1-BRIBERY-Reform-of-thePrevention-of-Corruption-Acts-and-SFO-.

45. The Law Commission, Reforming Bribery: a Consultation Paper (LC185) 23

(2007) [hereinafter LAW COMMISSION, CONSULTATION PAPER] available at http://lawcommission.justice.gov. UK/docs/cp185_Reforming_Bribery_consultation.pdf.

46. Id. at 25 .

47. The Serious Fraud Office is the UK entity that investigates and prosecutes serious 
connection with a major defense contract known as the AL Yamamah transaction. ${ }^{48}$ The size of the alleged bribes, $\$ 1$ billion, the alleged involvement of each British Prime Minister - Margaret Thatcher, John Major, and Tony Blair ${ }^{49}$ - and the television appearance of Saudi Prince Bandar bin Sultan apparently conceding the receipt of these bribes and saying "So what?" ${ }^{50}$ generated a great deal of media interest. ${ }^{51}$

Nevertheless, in December 2006 the Ministry of Justice announced that the SFO's investigation of BAE had been terminated. ${ }^{52}$ The cancellation of the investigation of BAE bribery immediately led to a challenge by two non-governmental organizations. ${ }^{53}$ An April 2008 decision of the High Court found that the SFO had improperly terminated its investigation. ${ }^{54}$ The House of Lords overturned this decision in July

fraud and currently is responsible for enforcing the Bribery Act 2010. See Who We Are, SERIOUS FRAUD OFFICE, www.sfo.gov.uk/about-us/who-we-are.aspx (last visited Mar. 4, 2012). The SFO was established by the Criminal Justice Act 1987. One of the functions of the office is to "investigate any suspected offence which appears to [the Director of the SFO] on reasonable grounds to involve serious or complex fraud." Criminal Justice Act, 1987, c. $38, \S 1$ (U.K.).

48. The Al Yamamah transaction extended over several decades and involved BAE supplying military aircraft, air defense and other systems to the Kingdom of Saudi Arabia. The Financial Times referred to this transaction as the "biggest sale ever, of anything, to anyone." David White \& Robert Mauthner, Britain's Arms Sale Of The Century, FIN. TIMES (London), July 9, 1988, at 7.

49. Panorama's principal allegation is that BAE, with approval of the UK's Ministry of Defence, made payments worth hundreds of millions of pounds over two decades to bank accounts under the personal control of Prince Bandar bin Sultan, the son of Prince Sultan bin Abdul Aziz who has been the Saudi Defence Minister since 1962. The documentary suggests that some of the payments were for the personal expenditure of Prince Bandar bin Sultan. The allegations raise further concerns about the shelving of the SFO investigation. They suggest that, since 1985, successive British governments under Prime Ministers Margaret Thatcher, John Major and Tony Blair have used Ministry of Defence bank accounts to facilitate corrupt payments to a foreign official. The Story So Far . . Background to the legal challenge, CONTROL BAE REOPEN THE SAUDI CORRUPTION INQUIRY (Feb. 13, 2008), http://www.controlbae.org.UK/ background/review.php.

50. Aljazeera News Arabic, Bandar Bin Sultan Saudi Money Is Mine and I Do What I Want With It, YouTUBE.cOM (Jan. 10, 2009), http://www.youtube.com/watch?v=FeXT3tuH6ls.

51. See, e.g. Saudi Prince 'Received Arms Cash,' BBC NEWs (June 7, 2007), http://news.bbc.co.uk/2/hi/uk_news/6728773.stm

52. Press Release, Serious Fraud Office, BAE Systems PLC/Saudi Arabia (Dec. 14, 2006), available at http://www.sfo.gov.UK/press-room/latest-press-releases/press-releases2006/bae-systems-plcsaudi-arabia. aspx.

53. See The Story So Far . . Background to the Legal Challenge, CONTROL BAE REOPEN THE SAUDI CORRUPTION INQUIRY (Feb. 13, 2008), http://www.controlbae.org.UK/background/ review.php. ("On 18 December 2006, four days after the SFO announcement, The Corner House and Campaign Against Arms Trade wrote to the UK Government arguing that the SFO's decision was unlawful and should be reversed. The legal challenge centred on the UK's obligations under the Organisation for Economic Co-operation and Development (OECD) Anti-bribery Convention, which Britain signed in 1997.").

54. $\mathrm{R}$ (on the Application of Corner House Research and Campaign Against Arms Trade) v. The Dir. of the Serious Fraud Office, [2008] EWHC 714. 
$2008 .^{55}$ It was during this four-year period of great public interest in the BAE matter that Parliament considered the Corruption Bill.

In March 2007, the government once again asked the Law Commission to "undertake a thorough review of our bribery laws with a view to fundamental reform and in so doing to look at the full range of structural options for the scheme of bribery offences." ${ }^{26}$ Accordingly, in November 2007, the Law Commission sought public comment on its new analysis of the bribery laws through yet another consultation. ${ }^{57}$ One year later, in October 2008, the Law Commission once again published a report and proposed a draft law, this time focusing, not on "corruption," but specifically on bribery. ${ }^{58}$ Just a few months later, at the end of March 2009, the Ministry of Justice released its version of the bribery bill. ${ }^{59}$ A Joint Parliamentary Committee held further hearings on the March 2009 draft bribery bill and issued its final report in July 2009, thirty-two years after enactment of the FCPA. ${ }^{60}$ During these hearings, a prominent London lawyer in July 2009 gave testimony that presents an understated view of the long process that culminated in the introduction of the Bribery Act. ${ }^{61}$ Jeremy Carver, a former partner at Clifford Chance and prominent in the activities of Transparency International, an international anti-corruption organization, commented upon the years of delay, public consultations, and redrafts of the Bribery Bill:

If any piece of legislation has been consulted on, it is this one. The difficulty, of course, has been that each body that has triggered a consultation, whether it is the Government, whether it is the Law Commission or previous parliamentary committees, has of course continued to receive the two points of view: one that says we must have legislation, it should be clear, it should be decisive and it should stop present malpractices, and the other says that, yes, we have legislation [sic] but basically we want to continue to do what we have always been doing and we do

55. House of Lords, Session 2007-08 [2008] UKHL 60, R v Dir. of the Serious Fraud Office, [2008] UKHL 60, A.C. (H.L.) (appeal taken from Eng.).

56. Written Ministerial Statements, Envtl. Food and Rural Affairs, Envtl. Council (Mar. 5, 2007), available at http://www.publications.parliament.UK/pa/cm200607/cmhansrd/cm070305/ wmstext/70305m0001.htm.

57. See LAW COMMISSION, CONSUltation PAPER, supra note 45.

58. See LAW COMMISSION, REFORMING BRIBERY 2008, supra note 36.

59. Bribery Bill, 2010, H.L. Bill [69] (Eng.); Ministry of Justice, Bribery: Draft Legislation.

60. JOINT COMMITTEE HOUSE OF COMMONS, REPORT, H.C. 430-I and H.L. 115-I (U.K.).

61. UNCORRECTED TRANSCRIPT OF ORAL EVIDENCE PUBLISHED AS HC 430 VI (June 11, 2009), available at http://www.publications.parliament.UK/pa/jt200809/jtselect/ jtbribe/uc430-vi/uc43002.htm. 
not want to risk losing British business. ${ }^{62}$

Four months later, the Bribery Bill 2009 was introduced into the House of Lords. ${ }^{63}$ From there, it was relatively speedily passed by both houses of Parliament, receiving Royal Assent on April 8, 2010. Even then, however, this law did not immediately go into effect. As described in Part III.C., infra, Section 9 of the Bribery Act required the government to publish guidance prior to the effective date of the Act to help businesses understand how to comply with the incomprehensible requirements of Section 7, the crime of failing to prevent bribery. ${ }^{64}$ The Ministry of Justice published final guidance to the Bribery Act 2010 on March 30, 2011 ("Guidance"). ${ }^{65}$ The Bribery Act 2010 became effective on July 1, 2011. ${ }^{66}$

Regardless of the years of delay, the Bribery Act is now in effect. We analyze the operative provisions of the Act in Parts II, III, and IV, infra.

\section{BRIBERY ACT: SECTIONS 1, 2, AND 6}

In Part II, we discuss three of the four substantive provisions of the Bribery Act. Section 1 of the Act prohibits what has been referred to as "active" bribery - the offering or payment of something of value to another. ${ }^{67}$ Unlike the exclusively foreign focus of the FCPA, Section 1 applies to domestic UK bribery as well. ${ }^{68}$ Section 2 , dealing with "passive bribery," proscribes receipt of a bribe. ${ }^{69}$ This offense also has general applicability, including within the United Kingdom. Section 6 outlines the offense of bribing a foreign public official. ${ }^{70}$

\section{A. Section 1: Bribery of Another Person}

Section 1 sets forth the offense of bribing another person, or what is

62. Id.

63. See Timothy Edmonds \& OONAGH Gay, Bribery Bill [HL], Bill No 69, RESEARCH PAPER 10/19 1, 6 (Mar. 2010).

64. Bribery Act, supra note $2, \S 7$.

65. See generally Ministry of JUSTICE, The Bribery ACt 2010: Guidance (2010) [hereinafter Guidance] available at http://www.justice.gov.UK/downloads/legislation/ bribery-act-2010-guidance.pdf. See also Bribery Act, supra note 2, § 9.

66. Guidance, supra note 65 , at 2 .

67. Bribery Act, supra note $2, \S 1$.

68. Indeed, the first prosecution under the Bribery Act was for receipt of a domestic bribe by an administrative officer in a magistrate's court in Redgate, England. See Press release, The Crown Prosecution Service, Court officer admits taking bribe in first prosecution under Bribery Act (Oct. 14, 2011), available at http://www.cps.gov.UK/news/ press_releases/127_11/index.html.

69. Bribery Act, supra note $2, \S 2$.

70. Id. $\S 6$. 
referred to as "active bribery."

(1) A person ("P") is guilty of an offence if either of the following cases applies.

(2) Case 1 is where-

(a) P offers, promises or gives a financial or other advantage to another person, and

(b) $P$ intends the advantage-

(i) to induce a person to perform improperly a relevant function or activity, or

(ii) to reward a person for the improper performance of such a function or activity.

(3) Case 2 is where -

(a) P offers, promises or gives a financial or other advantage to another person, and

(b) P knows or believes that the acceptance of the advantage would itself constitute the improper performance of a relevant function or activity.

(4) In case 1 it does not matter whether the person to whom the advantage is offered, promised or given is the same person as the person who is to perform, or has performed, the function or activity concerned.

(5) In cases 1 and 2 it does not matter whether the advantage is offered, promised or given by $\mathrm{P}$ directly or through a third party. ${ }^{72}$

Section 1 prohibits a person (either directly or indirectly) from offering, promising, or giving a financial or other advantage to another. This is a general bribery offense applicable both within the United Kingdom and abroad. An offense under Section 1 includes not only payments of money, but also offers, promises, or gifts of "financial or other advantage." ${ }^{73}$ Any such action constitutes a Bribery Act offense even without carrying through with the offer or promise of a payment or advantage; the offer or promise completes the offense. ${ }^{74}$ A Section 1 offense is limited to circumstances where the party making the payment intends the "advantage" so proffered to induce the recipient to improperly perform an act or to reward the recipient for having done so. ${ }^{75}$ The offense is also completed when a party offers such an advantage knowing that

71. Expansive Reach, supra note 8, at 325-26.

72. Bribery Act, supra note $2, \S 1$.

73. $I d . \S 1(2)(\mathrm{a})$.

74. Id. $\S 1(3)$.

75. Id. § $1(2)(\mathrm{b})$. 
acceptance of the advantage will result in the improper performance of a relevant function or activity. ${ }^{76}$

The key distinction between case 1 and case 2 described in Subsections (2) and (3) of Section 1 of the Act is the person to whom the advantage is offered. In case 1, it does not matter whether the person to whom the advantage is offered is the same person who is to perform, or has performed, the activity. In case 2, the person whose acceptance of the advantage constitutes an improper performance must be the same person to whom the advantage is offered. Moreover, in case 1, the advantage must be intended to induce or reward the improper performance of a relevant function or activity, whereas in case 2, the acceptance of the advantage itself is the improper performance. In summary, a person offering an "advantage" as described in Section 1 is guilty of active bribery if this was done with intent either to induce the recipient to act improperly or to reward the recipient for having done so. The offeror is also guilty of bribery where the recipient's acceptance or agreement to accept is itself improper.

\section{B. Section 2: Acceptance of a Bribe}

Section 2 of the Act describes the offense of "passive bribery," in which the perpetrator requests or agrees to receive a bribe. This section provides:

(1) A person ("R") is guilty of an offence if any of the following cases applies.

(2) Case 3 is where $R$ requests, agrees to receive or accepts a financial or other advantage intending that, in consequence, a relevant function or activity should be performed improperly (whether by R or another person).

(3) Case 4 is where-

(a) $R$ requests, agrees to receive or accepts a financial or other advantage, and

(b) the request, agreement or acceptance itself constitutes the improper performance by $\mathrm{R}$ of a relevant function or activity.

(4) Case 5 is where $R$ requests, agrees to receive or accepts a financial or other advantage as a reward for the improper performance (whether by $\mathrm{R}$ or another person) of a relevant function or activity.

(5) Case 6 is where, in anticipation of or in consequence of $\mathrm{R}$ requesting, agreeing to receive or accepting a financial or other advantage, a relevant function or activity is 
performed improperly-

(a) by $\mathrm{R}$, or

(b) by another person at R's request or with R's assent or acquiescence.

(6) In cases 3 to 6 it does not matter-

(a) whether $\mathrm{R}$ requests, agrees to receive or accepts

(or is to request, agree to receive or accept) the advantage directly or through a third party,

(b) whether the advantage is (or is to be) for the benefit of $\mathrm{R}$ or another person.

(7) In cases 4 to 6 it does not matter whether R knows or believes that the performance of the function or activity is improper.

(8) In case 6, where a person other than $\mathrm{R}$ is performing the function or activity, it also does not matter whether that person knows or believes that the performance of the function or activity is improper. ${ }^{77}$

For this offense, one does not need to receive a bribe, but merely ask for or agree to receive it, and the bribe need not be monetary. It can be a simple "advantage." As with active bribery, the action must be improper: the actor needs to do, or intend to do, something wrong. The improper conduct could be intended to be done by a third party, or a third party could be the source of the bribe. ${ }^{78}$ As we have noted elsewhere, "the irony of labeling this offense as passive bribery, and yet defining the four cases constituting varieties of the receipt of a bribe using the term 'requests,' was apparently lost on Parliament." remarked: "Calling it passive bribery...rather misses [the] point." 80

\section{Sections 3 and 4: "Relevant Function or Activity" and "Improper Performance"}

Sections 3 and 4 of the Act set forth the broad range of activities to which the Act applies and the meaning of "improper" performance as used in Section 1. As noted, a Section 1 offense is committed where the "advantage" is intended to either induce a person to perform improperly a relevant function or activity or reward a person for the improper performance of such a function or activity ${ }^{81}$ The same offense is committed

77. Bribery Act, supra note $2, \S 2$.

78. Id. § 2(6).

79. Expansive Reach, supra note 8.

80. Peter Alldridge, Reforming Bribery: Law Commission Consultation Paper 185: (1) Bribery Reform and the Law-Again, 2008 CRIM. L. R. 671, 681 (2008).

81. Bribery Act, supra note $2, \S 1(2)(b)$. 
where a person offers, promises, or gives a financial or other advantage to another, and such person knows or believes that the acceptance of the advantage would itself constitute the improper performance of a relevant function or activity. ${ }^{82}$

\section{1. "Relevant Function"}

Section 3 provides:

(1) For the purposes of this Act a function or activity is a relevant function or activity if-

(a) it falls within subsection (2), and

(b) meets one or more of conditions $\mathrm{A}$ to $\mathrm{C}$.

(2) The following functions and activities fall within this subsection-

(a) any function of a public nature,

(b) any activity connected with a business,

(c) any activity performed in the course of a person's employment,

(d) any activity performed by or on behalf of a body of persons (whether corporate or unincorporate).

(3) Condition $\mathrm{A}$ is that a person performing the function or activity is expected to perform it in good faith.

(4) Condition B is that a person performing the function or activity is expected to perform it impartially.

(5) Condition $\mathrm{C}$ is that a person performing the function or activity is in a position of trust by virtue of performing it.

(6) A function or activity is a relevant function or activity even if it-

(a) has no connection with the United Kingdom, and

(b) is performed in a country or territory outside the United Kingdom.

(7) In this section "business" includes trade or profession. ${ }^{83}$

Thus, a "relevant function or activity" includes any public or business activity performed in the course of employment ${ }^{84}$ that also meets one of three conditions: it is normally expected to be performed in good faith, is performed impartially, or is performed by a person in a position of trust. ${ }^{85}$ It

\footnotetext{
82. Id. \&1(2)(b), (3)

83. $I d . \S 3$.

84. Id.

85. Id. $\S 3(3,4,5)$.
} 
must be emphasized that the acting party is guilty even where the relevant function or activity is carried out abroad; such activity need not have any connection to the United Kingdom, and the measure of what is "improper" is determined by UK standards, not by those of the foreign country where the bribing occurs. ${ }^{86}$ This application of UK standards to transactions occurring in foreign nations with different societal mores and cultures will doubtless trigger accusations of "cultural imperialism" comparable to those previously raised in connection with application of the FCPA. ${ }^{87}$

\section{2. "Improper Performance"}

Section 4 provides:

(1) For the purposes of this Act a relevant function or activity-

(a) is performed improperly if it is performed in breach of a relevant expectation, and

(b) is to be treated as being performed improperly if there is a failure to perform the function or activity and that failure is itself a breach of a relevant expectation.

(2) In subsection (1) "relevant expectation"-

(a) in relation to a function or activity which meets condition $\mathrm{A}$ or $\mathrm{B}$, means the expectation mentioned in the condition concerned, and

(b) in relation to a function or activity which meets condition $\mathrm{C}$, means any expectation as to the manner in which, or the reasons for which, the function or activity will be performed that arises from the position of trust mentioned in that condition.

(3) Anything that a person does (or omits to do) arising from or in connection with that person's past performance of a relevant function or activity is to be treated for the purposes of this Act as being done (or omitted) by that

86. Id. $\S \S 4,5$.

87. See, e.g., Christopher J. Duncan, The 1998 Foreign Corrupt Practices Act Amendments: Moral Empiricism or Moral Imperialism, 1 ASIAN-PAC. L. \& POL'Y J. 16F (2000); Elizabeth Spahn, International Bribery: The Moral Imperialism Critiques, 18 MINN. J. INT'L L. 155, 156 (2009); Padideh Ala'i, The Legacy of Geographical Morality and Colonialism: A Historical Assessment of the Current Crusade against Corruption, 33 VAND. J. TRANSNAT'L L. 877, 881 (2000); see also Expansive Reach, supra note 8, at 328 n. 25. 
person in the performance of that function or activity. ${ }^{88}$

Thus, according to this section, a relevant function or activity is performed improperly if it is performed in breach of a relevant expectation, or if there is a failure to perform the function or activity, and that failure is a breach of a relevant expectation. ${ }^{89}$

\section{3. "British "Expectations"}

Section 5 of the Act elaborates on the term "expectation," as that term is used in Sections 3 and 4, and makes perfectly clear that the test of what is expected is a test of expectations in the United Kingdom. ${ }^{90}$ The full text of Section 5 is as follows:

(1) For the purposes of sections 3 and 4, the test of what is expected is a test of what a reasonable person in the United Kingdom would expect in relation to the performance of the type of function or activity concerned.

(2) In deciding what such a person would expect in relation to the performance of a function or activity where the performance is not subject to the law of any part of the United Kingdom, any local custom or practice is to be disregarded unless it is permitted or required by the written law applicable to the country or territory concerned.

(3) In subsection (2) "written law" means law contained in-

(a) any written constitution, or provision made by or under legislation, applicable to the country or territory concerned, or

(b) any judicial decision which is so applicable and is evidenced in published written sources. ${ }^{91}$

Once again, the Bribery Act requires that UK standards apply to conduct that occurs in other nations. The breach of a relevant expectation, for purposes for Section 4, follows a reasonableness test, based only on what is considered "reasonable" in the United Kingdom, and any local custom or practice is generally to be disregarded.

88. Bribery Act, supra note $2, \S 4$.

89. Id.

90. Id. $\S 5(1)$.

91. Id. $\S 5$ (emphasis added). 


\section{Section 6: Bribery of a "Foreign Public Official"}

Section 6 of the Act is the section that most directly parallels the FCPA offense of bribery of a foreign public official. Section 6 describes this offense as follows:

(1) A person ("P") who bribes a foreign public official ("F") is guilty of an offence if P's intention is to influence $F$ in F's capacity as a foreign public official.

(2) P must also intend to obtain or retain-

(a) business, or

(b) an advantage in the conduct of business.

(3) P bribes F if, and only if-

(a) directly or through a third party, $\mathrm{P}$ offers, promises or gives any financial or other advantage-

(i) to F, or

(ii) to another person at F's request or with

F's assent or acquiescence, and

(b) $\mathrm{F}$ is neither permitted nor required by the written law applicable to $F$ to be influenced in F's capacity as a foreign public official by the offer, promise or gift.

(4) References in this section to influencing $F$ in F's capacity as a foreign public official mean influencing $F$ in the performance of F's functions as such an official, which includes-

(a) any omission to exercise those functions, and

(b) any use of F's position as such an official, even if not within F's authority. ${ }^{92}$

To trigger liability under the Bribery Act, the bribe must be paid to a foreign public official. Who qualifies as such an official is defined in Section 6(5):

"Foreign public official" means an individual who-

(a) holds a legislative, administrative or judicial position of any kind, whether appointed or elected, of a country or territory outside the United Kingdom (or any subdivision of such a country or territory),

(b) exercises a public function-

92. Id. §6(1)-(4). 
(i) for or on behalf of a country or territory outside the United Kingdom (or any subdivision of such a country or territory), or

(ii) for any public agency or public enterprise of that country or territory (or subdivision), or

(c) is an official or agent of a public international organisation. ${ }^{93}$

This definition closely tracks the definition included in the OECD Convention:

For the purpose of this Convention:

a) "foreign public official" means any person holding a legislative, administrative or judicial office of a foreign country, whether appointed or elected; any person exercising a public function for a foreign country, including for a public agency or public enterprise; and any official or agent of a public international organization. ${ }^{94}$

A "public international organization" is defined in Section 6 of the Bribery Act:

"Public international organisation" means an organisation whose members are any of the following-

(a) countries or territories,

(b) governments of countries or territories,

(c) other public international organisations,

(d) a mixture of any of the above. ${ }^{-95}$

Furthermore, the Ministry of Justice asserts in the Guidance that an offense under Section 6 has no jurisdictional limit: a foreign public official includes anyone, whether elected or appointed, who holds a legislative, administrative, or judicial position of any kind of a country or territory outside the United Kingdom, and includes:

[A]ny person who performs public functions in any branch of the national, local or municipal government of such a

93. Id. §6(5).

94. OECD Convention, Article 1, subsection 4(a), available at http://www.oecd.org/ dataoecd/4/18/38028044.pdf (emphasis added).

95. Bribery Act, 2010, c. $23, \S 6(6)$ (U.K.). 
country or territory or who exercises a public function for any public agency or public enterprise of such a country or territory, such as professionals working for public health agencies and officers exercising public functions in stateowned enterprises. ${ }^{96}$

Such an official "can also be an official or agent of a public international organisation, such as the [United Nations] or the World Bank." 97

The policy underlying Section 6 addresses "the need to prohibit the influencing of decision making in the context of publicly funded business opportunities by the inducement of personal enrichment of foreign public officials or to [sic] others at the official's request." ${ }^{.98}$ While such activity is likely to involve conduct amounting to improper performance of a relevant function or activity, to which Section 1 applies, the Guidance explains that Section 6 does not require proof of improper performance or an intention to induce such performance. "[T] he exact nature of the functions of the persons regarded as foreign public officials is often very difficult to ascertain with any accuracy, and the securing of evidence will often be reliant on the co-operation of the state any such officials serve." ${ }^{, 99}$ The Guidance states that "it is not the Government's intention to criminalise behaviour where no such mischief occurs, but merely to formulate the offence to take account of the evidential difficulties referred to above."100 However, this statement provides no useful "guidance" at all, and will serve only to trouble those who regularly interact with foreign public officials and will now have to worry about their every move.

\section{E. Section 12: Jurisdictional Nexus to the United Kingdom}

Section 12 sets forth the scope of jurisdiction of the various operative provisions of the Bribery Act. Subsections (1) through (4) apply to Sections 1,2 , and 6 of the Act and are standard and unexceptional. They provide as follows:

Offenses under this Act: territorial application

96. Guidance, supra note 65 , at 922 (emphasis added).

97. Id. This expands slightly on the text of the OECD Convention, which provides that a foreign public official means any person holding a legislative, administrative or judicial office of a foreign country, whether appointed or elected; any person exercising a public function for a foreign country, including for a public agency or public enterprise; and any official or agent of a public international organization. OECD Convention, supra note 87 , available at http://www.oecd.org/dataoecd/4/18/38028044.pdf.

98. Guidance, supra note 65 , at 923.

99. Id.

100. Id. 
(1) An offence is committed under section 1,2 or 6 in England and Wales, Scotland or Northern Ireland if any act or omission which forms part of the offence takes place in that part of the United Kingdom.

(2) Subsection (3) applies if-

(a) no act or omission which forms part of an offence under section 1,2 or 6 takes place in the United Kingdom,

(b) a person's acts or omissions done or made outside the United Kingdom would form part of such an offence if done or made in the United Kingdom, and

(c) that person has a close connection with the United Kingdom.

(3) In such a case-

(a) the acts or omissions form part of the offence referred to in subsection (2)(a), and

(b) proceedings for the offence may be taken at any place in the United Kingdom.

(4) For the purposes of subsection (2)(c) a person has a close connection with the United Kingdom if, and only if, the person was one of the following at the time the acts or omissions concerned were done or made-
(a) a British citizen,
(b) a British overseas territories citizen,
(c) a British National (Overseas),
(d) a British Overseas citizen,
(e) a person who under the British Nationality Act 1981 was a British subject, (f) a British protected person within the meaning of that Act,

(g) an individual ordinarily resident in the United Kingdom,

(h) a body incorporated under the law of any part of the United Kingdom,

(i) a Scottish partnership.

(5) An offence is committed under section 7 irrespective of whether the acts or omissions which form part of the offence take place in the United 
Kingdom or elsewhere. ${ }^{101}$

This jurisdictional nexus to the United Kingdom is traditional. The territorial basis for jurisdiction is explicit in Subsection (1). ${ }^{102}$ Nationality jurisdiction is set out in Subsection (2). ${ }^{103}$ Under Subsection 2, a natural person subject generally to UK laws is subject to the Bribery Act even when acting outside the United Kingdom. These provisions are parallel to provisions of the FCPA as most recently amended in 1998 to comply with the OECD Convention. ${ }^{104}$

Subsection (5), however, thrusts the Act into a new, perilously overbroad area of hitherto untested, and in our view unjustified jurisdiction. "An offence is committed under section 7 irrespective of whether the acts or omissions which form part of the offence take place in the United Kingdom or elsewhere."105 This Parliamentary language contrasts starkly with the 1998 opinion of the legal experts on the Law Commission previously cited in Part I.C: "Under the present law, the English courts do not have jurisdiction to try a criminal offence unless the last act or event necessary for its completion occurs within the jurisdiction.",106

SFO Senior Staff have explained that the test for jurisdiction is whether the company in question carries out business in the United Kingdom, and that this is also a fact-specific inquiry to be made on a caseby-case basis. ${ }^{107}$ This means that to resolve each particular factual setting, the defendant non-UK business entity must go to trial - incurring significant costs and delays to determine whether it is actually subject to the expansive grasp of the Bribery Act. The SFO has also made quite clear that it "intends to assert broad jurisdiction under the provisions of the Bribery Act." 108 This jurisdictional overreach of the Bribery Act applies only to Section 7, which creates the unique, strict corporate liability crime of failing to prevent a bribe, which does not require fault or any inkling of mens rea. Given the central role of London in many aspects of international business, this crime may apply to almost all transnational businesses, including those with only the slightest connection to the United Kingdom. Furthermore, as detailed in Part IV, infra, the Bribery Act's version of a "bribe" includes

101. Bribery Act, supra note $2, \S 12$.

102. Id. $\S 12(1)$.

103. Id. $\S 12(2)$.

104. See Prohibited Foreign Trade Practices by Persons Other Than Issuers or Domestic Concerns 15 U.S.C. $\S 78 \mathrm{dd}-3$ (a), (f)(1) (2011).

105. Bribery Act, supra note $2, \S 12(5)$ (U.K.) (emphasis added).

106. THE LAW COMMISSION, supra note 31 , at 103.

107. See generally GUIDANCE, supra note $65, \uparrow 34$.

108. UK Serious Fraud Office Discusses Details of UK Bribery Act, GIBSON DUNN, http://www.gibsondunn.com/publications/pages/UKSeriousFraudOfficeDiscussionRecentlyEnactedUKBriberyAct.aspx (Sept. 7, 2010) [hereinafter Dunn Article]. 
expenditures routinely made by businesses today.

\section{SECTION 7: YOU ARE GUILTY}

The Bribery Act's Section 7, "Failure of commercial organisations to prevent bribery," is innovative, unprecedented, and indefensible as applied to non-UK registered businesses. It is a strict liability crime applicable to a business "doing business or a part of a business in the UK."109 While the Bribery Act has several unclear, ambiguous provisions, Section 7 is by far the most objectionable. As we explained in Part II.D, supra, Subsection 12(5) of the Bribery Act imposes no territorial limits on the applicability of the unique crime of "failure to prevent bribery." As described more fully in Part IV B, infra, following its careful review of the issue, the Law Commission's draft bribery bill did not include strict liability for failing to prevent bribery. Because London is a world class financial center, travel hub, and attractive international destination, the crime of failing to prevent a bribe is potentially applicable to most of the world's business entities that have cross border operations.

As its justification for asserting this vast extraterritorial reach for the Bribery Act, the SFO reported that it has been approached by UK companies complaining about competitors in foreign countries that are paying bribes. The SFO recognized the disadvantage compliance with the Act will pose and stated that one of its objectives is "to prevent ethical companies from being competitively disadvantaged by the actions of other companies whether they are within or outside the UK." ${ }^{110}$ This is somewhat ironic since no UK firm, including BAE, had ever been prosecuted in the United Kingdom for overseas bribery until 2009. This was twelve years after the OECD Convention was signed, when the first, and only, violation was penalized as the result of a company self-reporting a breach of the United Nations Iraq Oil for Food sanctions. ${ }^{11}$

We now turn to a closer analysis of the offending provisions of Section 7. This section reads in relevant part:

(1) A relevant commercial organisation ("C") is guilty of an offence under this section if a person ("A") associated with $\mathrm{C}$ bribes another person intending -

(a) to obtain or retain business for $\mathrm{C}$, or

(b) to obtain or retain an advantage in the conduct

109. Bribery Act, supra note $2, \S 7(5)$.

110. Dunn Article, supra note 108, at 4.

111. Press Release, Serious Fraud Office, Maybe \& Johnson Ltd: Former executives jailed for helping finance Saddam Hussein's government, (Feb. 23, 2011), available at http://www.sfo.gov.UK/press-room/latest-press-releases/press-releases-2011/mabey--johnsonItd-former-executives-jailed-for-helping-finance-saddam-hussein's-government.aspx. 
of business for $\mathrm{C}$.

(2) But it is a defence for $\mathrm{C}$ to prove that $\mathrm{C}$ had in place adequate procedures designed to prevent persons associated with $\mathrm{C}$ from undertaking such conduct.

(3) For the purposes of this section, A bribes another person if, and only if, A-

(a) is, or would be, guilty of an offence under section 1 or 6 (whether or not $\mathrm{A}$ has been prosecuted for such an offence), or

(b) would be guilty of such an offence if section 12(2)(c) and (4) were omitted.

(4) See section 8 for the meaning of a person associated with $\mathrm{C}$ and see section 9 for a duty on the Secretary of State to publish guidance. ${ }^{112}$

To fully appreciate the broad scope of Section 7, we need to determine the meaning of "relevant commercial organization" and of "person associated" with such an organization. In the Bribery Act, these terms are ambiguous, elusive, and open-ended.

\section{A. Relevant Commercial Organization}

The application of Section 7 to a UK commercial enterprise is not troubling. Such an organization is a "body which is incorporated under the law of any part of the United Kingdom and which carries on a business (whether there or elsewhere)," or "a partnership which is formed under the law of any part of the United Kingdom and which carries on a business (whether there or elsewhere)."113 This portion of the definition is unexceptional, reflecting traditional territorial jurisdiction. UK domiciled entities are subject to the strict criminal liability of Section 7 (with only the defense set out in Section 7(2)). ${ }^{114}$ It is well accepted that if an organization is established in any part of the "United Kingdom," Parliament has the power to legislate as it sees fit. ${ }^{115}$

As described infra, however, Parliament determined that Section 7 is equally applicable to "(b) any other body corporate (wherever incorporated) which carries on a business, or part of a business, in any part of the United Kingdom, [or] . . . (d) any other partnership (wherever

112. Bribery Act, supra note $2, \S 7(1-4)$ (emphasis added).

113. Id. $\S 7(5)$.

114. Id. $\S 7(2)$.

115. The term "United Kingdom" is defined in Section 12 of the Bribery Act as England, Wales, Scotland, and Northern Ireland, and does not include British "overseas territories" such as Bermuda, the Falkland Islands, or the British Virgin Islands. See Id. § 12. 
formed) which carries on a business, or part of a business, in any part of the United Kingdom...."116 Jurisdiction over a non-UK company "which carries on a business" in the United Kingdom is unobjectionable. The overly broad aspect of this provision is found in the phrase "which carries on ... part of a business, in any part of the United Kingdom." 117 We find no explanation of what "carries on ... part of a business" might entail in either the Act or the Guidance. Speeches by current and former UK officials from the SFO or Ministry of Justice similarly offer no useful clue to the meaning of this phrase. ${ }^{118}$ The Ministry of Justice did seek to ease concerns by stating:

The Government would not expect... the mere fact that a company's securities have been... admitted to trading on the London Stock Exchange, in itself, to qualify that company as carrying on a business or part of a business in the UK and therefore falling within the definition of a 'relevant commercial organisation' for the purposes of section $7 .{ }^{119}$

This should have been good news for the many foreign companies which have secured listings on, for example, the London Stock Exchange. However, Richard Alderman, at the time head of the SFO, the agency principally charged with enforcing the Bribery Act, flatly contradicted the Ministry by stating his view of SFO jurisdiction.

Asked whether all companies listed in the UK potentially fall under the remit of the Bribery Act, he said: "Exactly. You bet we will go after foreign companies. This has been misunderstood. If there is an economic engagement with the UK then in my view they are carrying on business in the UK. ${ }^{120}$

116. Id. $\S \S 7(5)(\mathrm{b}), 7(5)(\mathrm{d})$ (U.K.) (emphasis added).

117. Id. (emphasis added).

118. See, e.g., Richard Alderman, Dir., Serious Fraud Office, Speech at British Bankers Association Financial Crime Office, (Nov. 29, 2011) available at http://www.sfo.gov.uk/ about-us/our-views/director's-speeches/speeches-2011/british-bankers'-association-financialcrime-conference.aspx; Bribery Act In Force July 2011: Ken Clark's Statement In Full, THEBRIBERACT.COM (last visited Sept. 26, 2012 5:34 PM) http:/thebriberyact.com/ 2011/03/30/bribery-act-in-force-from-july-1-ken-clarkes-statement-in-full/ (last visited Nov. 7, 2012).

119. GUIDANCE, supra note 65, ๆ 36.

120. Jonathan Russell, Serious Fraud Office Risks Clash with Ministry of Justice over Bribery Act, THE TELEGRAPH, (Jul. 1, 2011, 5:45 AM BST), http://www.telegraph.co.uk/ finance/yourbusiness/bribery-act/8609486/Serious-Fraud-Office-risks-clash-with-Ministry-ofJustice-over-Bribery-Act.html. "Foreign companies with any kind of business link with the UK 
If a listing on a stock exchange in London fits within this new term, "economic engagement," what about a syndicated credit facility that includes London banks? What about the occasional sale of a product or the increasingly common provisions in international agreements which provide for dispute resolution in London, either in the Commercial Courts or at the London Court of International Arbitration? Perhaps the English courts will one day resolve this uncertainty. ${ }^{121}$ For the present it is extremely unsettling for companies that might be ensnared by Alderman's grandiose view of his jurisdiction under the Bribery Act to see authoritative UK spokesmen expounding inconsistent views on what is, by any measure, an extraordinarily far-reaching provision.

\section{B. "Adequate Procedures" Defense}

Parliament claimed to ameliorate the draconian impact of the automatic imposition of criminal liability for failing to prevent a bribe by offering one possible defense to the crime, the marvelously labeled "adequate procedures" defense. Section 7(2) provides, "But it is a defence for $\mathrm{C}$ to prove that $\mathrm{C}$ had in place adequate procedures designed to prevent persons associated with $\mathrm{C}$ from undertaking such conduct." ${ }^{122}$ With the establishment of the strict liability Section 7 offense, when seeking to find liability in a legal entity, the prosecutor need no longer search for the person representing the "controlling mind" of the company. ${ }^{123}$ No criminal intent or knowledge, no guilty mind or mens rea, is required for this crime. If a "bribe" within the Bribery Act's very broad meaning of that term occurs, ${ }^{124}$

have been put on notice by the head of the Serious Fraud Office that they will be fair game once the biggest overhaul of the nation's bribery laws in a generation comes into force. Richard Alderman, the agency's director, is charging his investigators with rooting out bribery anywhere in the world when the legislation is introduced on July 1 . The Bribery Act's sweeping powers mean that companies based overseas come under the SFO's jurisdiction if they have any business link with the UK, such as being listed here." Caroline Binham, SFO Chief Warns of New Global Reach, FINANCIAL TIMES (May. 23, 2011, 10:34 pm), http://www.ft.com/ intl/cms/s/0/8c056ce2-8562-1 le0-ae32-00144feabdc0.html\#axzzl im4KhsYA.

121. See, e.g., GUIDANCE, supra note $65, \uparrow 34$ "The courts will be the final arbiter as to whether an organization 'carries on a business' in the UK taking into account the particular facts in individual cases." Id.; Dunn Article, supra note 108, at 2 ("However, they made clear that the test for jurisdiction is simply whether the company in question carries out business in the United Kingdom. They noted that case law relating to this question will not necessarily be relevant to determining jurisdiction, and this will be a matter of fact in each case, clarifying that the SFO intends to assert broad jurisdiction under the provisions of the Bribery Act.").

122. Bribery Act, supra note $2, \S 7(2)$.

123. The "controlling mind" element of a corporate prosecution under prior UK law required proof that a very senior executive of the defendant corporation actively and knowingly affected the bribe. This is the stated explanation for why there were so few corporate defendants prosecuted under the Prevention of Corruption Acts 1889-1916. See, e.g., Tesco Ltd. v. Nattrass, [1971] A.C. 153 (H.L.) 160-61 (appeal taken from Eng.) (U.K.).

124. For discussion of grease and hospitality payments, see Part IV A., infra. 
the corporate or other commercial entity is guilty, despite having no knowledge of the alleged bribe and despite having taken no affirmative act in connection with this "crime." To avoid this automatic guilty verdict, the company must prove that it "had in place adequate procedures designed to prevent persons associated with [the company] from undertaking such conduct." 125

Use of the term "adequate" is curious, since obviously had the procedures actually been adequate, the bribery would not have occurred in the first place. ${ }^{126}$ Substitution of the term "reasonable" was considered and rejected in Parliament. ${ }^{127}$ The UK Law Commission published a Summary of its Recommendations, which explained the Section 7 defense in the following terms: "[I]t will generally be sufficient guidance to those in a position to make payments to say: Do not make payments to someone (or favour them in any other way) if you know that this will involve someone in misuse of their position." ${ }^{128}$ However, this statement is perfectly circular. To say one cannot engage in bribery because it is bribery is unusually unhelpful. When the Law Commission Report was being considered by legislators, testimony to the Joint Committee of Parliament considering the draft Bribery Bill challenged the public policy basis of Section 7: "We fail to see why public policy should require that individual's actions be criminalized and for the individual to then to rely on a prosecutor's discretion, on whether with hindsight, the public interest requires a prosecution." 129 The final version of the Act retained the strict liability provision of the draft along with the adequate procedures defense.

\section{The Ministry of Justice's "Guidance"}

In the clearest possible acknowledgement of the unique challenge posed by Section 7 and its sole affirmative defense, Parliament included in the Act a highly unusual provision. Section $9^{130}$ requires that the UK

125. Bribery Act, supra note $2, \S 7(2)$.

126. See Joseph Heller, Catch 22 (Simon \& Schuster 1996) (1955).

127. PUBLIC BILL COMMITTEE, BRIBERY BILL AMENDMENTS, H.C. 55-69 (Mar. 16, 2010) (U.K.), available at http://www.publications.parliament.uk/pa/cm200910/ cmpublic/bribery/100316/pm/100316s03.htm

128. THE LAW COMMISSION, REFORMING BRIBERY (LAW COM NO 313), 2008, at xvii, (U.K.) available at http://lawcommission.justice.gov.uk/docs/cp185 Reforming_Bribery_report.pdf.

129. Memorandum submitted by Herbert Smith LLP to Joint Comm., (BB 49) (Jun. 2009) available at http://www.publications.parliament.uk/pa/jt200809/jtselect/jtbribe/memo/ 430/ucm4902.htm (U.K.).

130. Section 9 provides, in relevant part: "The Secretary of State must publish guidance about procedures that relevant commercial organisations can put in place to prevent persons associated with them from bribing as mentioned in section 7(1)." Bribery Act, supra note 2, $\S 9$. 
government provide guidance to the business community to explain how to comply with the strict liability offense of "Failing to Prevent Bribery." Upon careful review of the Ministry of Justice Guidance, published in final form in March 2011, eleven months after the Bribery Act was enacted, one can only conclude that the Guidance is not a useful guide to complying with the Act and avoiding Section 7 liability.

In his March 2011 Introduction to the final Guidance, Kenneth Clarke, the Justice Minister, offered this disclaimer of responsibility: "The question of whether an organisation had adequate procedures in place to prevent bribery in the context of a particular prosecution is a matter that can only be resolved by the courts taking into account the particular facts and circumstances of the case. ${ }^{\prime 31}$ Thus, the Justice Minister confirmed that the question of how a company is to comply with Section 7 of the Act is actually impossible to describe. While the Guidance characterizes Section $7(2)$ as a "full defense" to a violation of the strict liability crime of failing to prevent bribery, it makes clear that the burden is on the guilty organization to prove this defense providing that "[i]n accordance with established case law, the standard of proof which the commercial organisation would need to discharge in order to prove the defence, in the event it was prosecuted, is the balance of probabilities." 132

Rather than offering a clear route to satisfactory compliance with Section 7 , something we may presume Parliament had in mind when it required the Guidance to be published prior to the entire Act becoming effective, ${ }^{133}$ the Justice Ministry's Guidance simply repeats that the seemingly impossible burden is upon the guilty company to prove that its procedures were adequate, despite the failure of those procedures. While the Guidance offers six principles that serve as criteria to be used in determining whether companies had in place "proportionate procedures" for preventing bribery, the Ministry acknowledged that these principles "are intended to be flexible and outcome focused, allowing for the huge variety of circumstances that commercial organisations find themselves in."134 Thus, companies cannot practically rely on the Guidance to assist them with the "huge variety" of scenarios in which they might find themselves.

It bears emphasizing that the Guidance itself, while mandated by Section $9,{ }^{135}$ is not law, does not have the force of law, and merely expresses what some in the current Government think, hope, or believe. Even if the Guidance was clear, and it is not, it could not be relied upon.

131. See GUIDANCE, supra note 65, $\uparrow$.

132. GUIDANCE, supra note 65 , \ 33.

133. Bribery Act, supra note $2, \S 9$.

134. GUIDANCE, supra note 65, at p. 20.

135. "The Secretary of State must publish guidance about procedures that relevant commercial organisations can put in place to prevent persons associated with them from bribing as mentioned in section 7(1)." Bribery Act, 2010, c.23, §9 (U.K.). 
The Courts may find it interesting that the Guidance provides that decisions to prosecute must be guided by a "common sense" approach. ${ }^{136}$ But this is not an especially useful guide for business, and the courts will certainly come to their own independent conclusions. Governments change. And once an ambitious prosecutor has made the decision to proceed under a particular set of attractive facts, and the media seek to boost sales by hyping another "corporate scandal" on its $24 / 7$ news cycle, stale statements of the intentions of a prior government will likely provide little protection for a business automatically found guilty under Section 7 .

\section{SO THEN, WHAT IS "BRIBERY?"}

Our review of the phrase "part of a business" in Part III.A. supra established that almost any commercial organization engaged in international business may find itself subject to prosecution under the Bribery Act. Given the unhelpful nature of the Guidance and the apparent attempt by Parliament to regulate international transactions with precious little connection with the United Kingdom, it is vital to fully understand just how broad the scope of the term "bribe" is as used in the Act if a company is to avoid the unlimited fines of the automatic crime of failing to prevent a bribe.

\section{A. The New Definition of Bribe}

Section 7 applies to a "relevant commercial organization."137 In the globalized world of the twenty-first century where, for many purposes, electronic communications and the ease of international travel have virtually eliminated sovereign borders for businesses, any "relevant commercial organization," no matter its jurisdiction of organization or its primary business focus, may become subject to the Bribery Act if it can be argued that such organization does "part" of its business in the UK. Given the borderless application of the Bribery Act promised by its enforcers, we do need to understand the boundaries of what constitutes an actionable "bribe" under the Act. To make clear the expansive scope of the Bribery Act, we consider the meaning of "associated person," and two additional terms: "facilitation" payments and "hospitality" expenses.

\section{1. "Associated Person"}

Section 7 provides that the act constituting the alleged "bribe"

136. GUIDANCE, supra note 65 , at 2,15 . "And, as I hope this guidance shows, combating the risks of bribery is largely about common sense, not burdensome procedures." GUIDANCE, supra note 65 , at 2.

137. Bribery Act, supra note $2, \S 7(5)$. 
triggering potential criminal liability can be made by "a person associated with" such organization as long as that person had the intent to obtain or retain business or an "advantage" for such organization. ${ }^{138}$ The Bribery Act defines an "associated person" in Section 8:

(1) For the purposes of section 7, a person ("A") is associated with $\mathrm{C}$ if (disregarding any bribe under consideration) $\mathrm{A}$ is a person who performs services for or on behalf of $\mathrm{C}$.

(2) The capacity in which A performs services for or on behalf of $C$ does not matter.

(3) Accordingly A may (for example) be C's employee, agent or subsidiary.

(4) Whether or not A is a person who performs services for or on behalf of $\mathrm{C}$ is to be determined by reference to all the relevant circumstances and not merely by reference to the nature of the relationship between $\mathrm{A}$ and $\mathrm{C}$.

(5) But if $\mathrm{A}$ is an employee of $\mathrm{C}$, it is to be presumed unless the contrary is shown that $A$ is a person who performs services for or on behalf of $\mathrm{C}^{139}$

The potential for expansive use of this definition by SFO prosecutors is starkly evident. Subsection (4) explains that "all the relevant circumstances" are more significant than the nature of the actual relationship of that individual to the organization. This renders the term "associated person" even more ambiguous and significantly expands the potential reach of this strict criminal law. ${ }^{140}$ Based upon a straightforward reading of Subsection $8(5)$, executives and other employees of an organization are presumed to be associated with an organization. ${ }^{141}$ We have to accept that all employees, even temporary or part-time employees, are subject to the presumption in Subsection 8(5) that places the burden of proof upon the company to establish that the particular employee who is said to have effected a bribe was not, under "all the relevant circumstances," performing services "for or on behalf of" the company.

138. Id. $\S 7(1)(\mathrm{a})-(\mathrm{b})$.

139. Id. $\$ 8$.

140. It is interesting to note that, Richard Alderman, SFO Chief until April 2012, has contested the fairly obvious conclusion that the Bribery Act contains a number of ambiguities. Alderman has said: "Let me also say that I disagree with the comment that the Bribery Act is unclear. It is a model of clarity and has been widely praised." Mike Koehler, A Conversation with Richard Alderman - Director of the United Kingdom Serious Fraud Office, at 5 (Oct. 4, 2010) (unpublished working paper), available at http://ssrn.com/ abstract $=1687299$.

141. Bribery Act, supra note $2, \S 8(5)$. 
But who or what is an agent under Subsection (3) of Section 8? In the FCPA, "agent" likewise is not defined. ${ }^{142}$ However, the US common-law definition of "agent" would likely be applied to the FCPA. Under the common law, "[a]n agent is a person or entity that has been either explicitly or implicitly authorized to act on behalf of [a principal]"; "[w]hen the agent acts within the scope of its authority, the principal can be held liable for the agent's actions." 143 As reported FCPA cases reveal, local "consultants" have been used in an attempt to circumvent the FCPA's bribe standard. ${ }^{144}$ Hiring local persons to act on behalf of a company is a common practice in international business. Having such persons handle payments to local officials is a practice well known to prosecutors. Including local consultants who clearly do perform services for a business as "agents" for purposes of determining "associated person" is essential and not at all controversial. However, business in the twenty-first century also necessarily involves reliance upon many other types of what may be colloquially referred to as agents. These may include a very wide scope of persons and other businesses - delivery and maintenance people, designers, computer programmers, etc., all of whom perform services and may thus be deemed "associated" with a business. Commercial organizations, subject to, or that may be subject to, the Act would certainly benefit from useful guidance on how to avoid liability when dealing with such agents.

With respect to the term "subsidiary" in Subsection 8(3), Parliament has not singled this term out for special treatment, but rather, has lumped subsidiaries together with "employee" and "agent." It is logical to agree with Parliament's decision to overcome the long-standing fictional "separate existence" of a corporate subsidiary and to accept that acts taken by a wholly-owned subsidiary are, in fact, acts done "for or on behalf of" its

142. The FCPA provides, "[i]t shall be unlawful for any domestic concern ..., or for any officer, director, employee, or agent of such domestic concern . . ., to make use of the mails or any means or instrumentality of interstate commerce corruptly in furtherance of an offer, payment, [or] promise to pay ... anything of value to ... any person, while knowing that all or a portion of such money ... will be offered, given, or promised, directly or indirectly, to any foreign official . . . for purposes of ... influencing any act or decision of such foreign official . . in his ... official capacity ...." Anti-Bribery and Books \& Records Provisions of the Foreign Corrupt Practices Act (FCPA), Prohibited Foreign Trade Practices by Domestic Concerns, 15 U.S.C. $\S$ 78dd-2(a) (2004).

143. Joseph P. Covington ET AL., JENNER \& BLOCK'S FOREIGN CORRUPT PRACTICES ACT (FCPA) BUSINESS GUIDE, 15 (2012), available at http://jenner.com/ system/assets/assets/6349/original/Jenner_20_26_20Block_20FCPA_20Business_20Guide 2012.pdf?1334067320 (citing JONATHAN $\bar{M}$. PURVER, AMERICAN JURISPURDENCE PROOF OF FACTS, LIABILITY OF PARENT CORPORATION FOR ACTS OF SUBSIDIARY, $\S 2$ (2d 2009)).

144. See, e.g., Sherman \& Sterling, LLP, FCPA Digest of Cases and Review Releases Relating to Bribes to Foreign Officials Under the Foreign Corrupt Practices Act of 1977, FCPA Digest, Jan. 3, 2012, at 2, 22, (discussing United States v. Maxwell Technologies, No. 3:11-00329 (S.D. Cal. 2011)). 
parent. ${ }^{145}$ Genuine questions, however, arise under Section 8 for joint ventures and for subsidiaries that are not wholly-owned. Where ownership of a subsidiary is shared with others, the subsidiary may well still be performing services for or on behalf of the company. Is that partial parent always to be held responsible for bribes made by such subsidiary? Even for entities organized under the laws of a foreign jurisdiction? Even for bribes completely unrelated to the services such subsidiary or joint venture does perform for the company? Even when the company has "adequate procedures" overall, but because of its partial ownership arrangement, does not have operational control of the joint venture or subsidiary where the bribe occurred? These questions arise because the Act does not specify what is to be done when such situations arise, and the Guidance does not help at all.

The Guidance does not distinguish between wholly-owned and partially-owned subsidiaries. ${ }^{146}$ Rather, the Ministry of Justice focuses on the overall intent requirement of the Act, stating that " $[w]$ ithout proof of the required intention [to obtain or retain business or an advantage in the conduct of business for the organization], liability will not accrue through simple corporate ownership or investment, or through the payment of dividends or provision of loans by a subsidiary to its parent."147 The Ministry further states, in unhelpful language, that the question of "adequacy of bribery prevention procedures will depend in the final analysis on the facts of each case, including matters such as the level of control over the activities of the associated person . .".148 Thus, the Ministry once again states the not-so-helpful assertion that ultimate liability is fact-specific, will rest on the context of each case, and thus must be determined by a court.

Further questions concern entities in a company's supply chain. As the Guidance points out, "an organisation is likely only to exercise control over its relationship with its contractual counterparty" and persons who contract with that counterparty "will be performing services for the counterparty and not for other persons in the contractual chain." 149 The confusion arising from the numerous parties that may be involved in such transactions would provide an aggressive prosecutor with an opportunity to expand the scope of the Act even further. While many laws that businesses

145. See, e.g., Mazza v. Verizon Washington D.C., Inc., 852 F. Supp. 2d 28, 41 (D.D.C. 2012) ("Disregarding the separate identities of a corporate parent and its subsidiary is . . a rare exception grounded in equity considerations, and is only to be applied when adherence to the fiction of the separate existence of the corporation would sanction a fraud or promote injustice." Id. (internal quotations and citations omitted).

146. See generally GUIDANCE, supra note 65 , शๆ 33-43.

147. GUIDANCE, supra note $65, \Upsilon 42$.

148. GUIDANCE, supra note 65, \ 43.

149. GUIDANCE, supra note 65, ๆ 39. 
face are carefully crafted with somewhat ambiguous terms, providing prosecutors with the flexibility essential to address novel situations, Section 7 of the Bribery Act establishes a corporate crime requiring no affirmative act and with no element of mens rea. Thus, the possibility exists that a person only marginally associated with a company which is only marginally connected to the United Kingdom, may commit an act, whether deliberately or inadvertently, that triggers the strict criminal liability and unlimited fines of the Bribery Act. Such ambiguities in the Act are ill-advised.

\section{Facilitation Payments}

Unlike the FCPA, which explicitly permits facilitation payments, ${ }^{150}$ the Bribery Act provides no exception for what are referred to as "grease payments," "speed money," "tea money," or "facilitation payments." As described in the FCPA, these are the payments made to facilitate or expedite routine government action that international travelers may experience even in non-commercial circumstances. ${ }^{151}$ The Ministry of Justice, in an attempt to justify the Act's hardline stance on facilitation payments, provides in the Guidance:

As was the case under the old law, the Bribery Act does not (unlike US foreign bribery law) provide any exemption for such payments. The 2009 Recommendation of the Organisation for Economic Co-operation and Development [OECD] recognises the corrosive effect of facilitation payments and asks adhering countries to discourage companies from making such payments. Exemptions in this context create artificial distinctions that are difficult to enforce, undermine corporate anti-bribery procedures, confuse anti-bribery communication with employees and

150. 15 U.S.C. $\S \S 78 d d-1(b), 78 d d-2(b), 78 d d-3(b)$ (1998). For a description of the legislative history of the FCPA as it relates to facilitation payments and the addition in 1988 of explicit language authorizing these payments, see Michael S. Diamant \& Jesenka Mrdjenovic, Don't You Forget About Me: The Continuing Viability of the FCPA's Facilitating Payments Exception, 73 OHIO ST. L. J. 19, 19 (2012) available at http://moritzlaw.osu.edu/students/groups/oslj/files/2012/06/Furthermore.Diamant.pdf.

151. The FCPA defines "routine governmental action" as "only an action which is ordinarily and commonly performed by a foreign official in-(i) obtaining permits, licenses, or other official documents to qualify a person to do business in a foreign country; (ii) processing governmental papers, such as visas and work orders; (iii) providing police protection, mail pick-up and delivery, or scheduling inspections associated with contract performance or inspections related to transit of goods across country; (iv) providing phone service, power and water supply, loading and unloading cargo, or protecting perishable products or commodities from deterioration; or $(v)$ actions of a similar nature." 15 U.S.C. $\S \S 78 d d-1(f)(3)(A)(i)-(v), 78 d d-3(f)(4)(A), 78 d d-2(h)(4)(A)$. 
other associated persons, perpetuate an existing 'culture' of bribery and have the potential to be abused. ${ }^{152}$

The Guidance explains that these payments could trigger either the Section 6 offense or, "where there is an intention to induce improper conduct, including where the acceptance of such payments is itself improper, the section 1 offense and therefore potential liability under section 7."

Various explanations of the United Kingdom's position on facilitation payments, however, contain acknowledgements that a strict prohibition of all such payments will not be easily enforced. The Home Office noted in its December 2005 invitation for consultation on bribery and corruption laws:

There is no exemption for facilitation payments under our law: the making of any payment would be an offence under our law, if corruptly made. However, given the need to be realistic about the situations that may be faced in some overseas countries, the following statement has been made, with the agreement of the Director of Public Prosecutions: "We do not think it is desirable for UK law to apply differently overseas to the way it applies in the UK. We do not tolerate "facilitation payments" to UK officials. However it is difficult to envisage circumstances in which the making of a small "facilitation payment", extorted by a foreign official in countries where this is normal practice, would of itself give rise to a prosecution in the UK._The making of such payments may well, however, be illegal under the law of the country concerned.", 54

Likewise, Richard Alderman, Director of the SFO at the time the Guidance was first published, acknowledged the difficulty with prohibiting facilitation payments, stating in part:

I do not expect facilitation payments to end the moment the Bribery Act comes into force. What I do expect though is for corporates who do not yet have a zero tolerance approach to these payments, to commit themselves to such an approach and to work on how to eliminate these

152. Guidance, supra note 65 , $\$ 45$.

153. Guidance, supra note 65, ๆ 44.

154. Reform of the Prevention of Corruption Acts and SFO Powers in Cases of Bribery of Foreign Officials - A Consultation Paper, NORTHERN IRELAND OFFICE, If 27 (Dec. 2005), (emphasis added). 
payments over a period of time. ${ }^{155}$

Mr. Alderman has never explained how his "zero tolerance" for facilitation payments could be implemented "over a period of time" while complying with the absolute prohibition of such payments under the Act. Alderman's "solution" is one only a government regulator, totally immersed in the politics of London and totally removed from the realities of the world outside London, could offer.

As mentioned above, the United States' FCPA explicitly does not prohibit "facilitating" or "expediting" payments made to government officials for performing clerical or ministerial activities, or other "routine governmental actions." ${ }^{156}$ However, in practice, the precise meaning of "facilitating" payment under the FCPA remains unclear. The exception has been narrowed by government enforcement actions and settlements. ${ }^{157}$ In its Bribery Act Guidance, the Ministry of Justice does not shed light on Alderman's "zero tolerance" approach to facilitation payments. ${ }^{158}$ Rather, it ignores the conclusions of the Home Office in $2005^{159}$ and informs us that "[e]xemptions in this context create artificial distinctions that are difficult to enforce, undermine corporate anti-bribery procedures, confuse anti-bribery communication with employees and other associated persons, perpetuate an existing 'culture' of bribery and have the potential to be abused." 160 It is surely exasperating for businesses seeking to comply with the Bribery Act to realize that the Act flatly outlaws and thus automatically criminalizes, what Parliament and the SFO acknowledge are common practices around the world.

Mr. Alderman's prosecutors did offer criteria that they would consider in evaluating whether to prosecute a company that does make facilitation payments after the effective date of the Bribery Act. Specifically, the SFO has said that it would examine:

1. whether the company has a clear issued policy regarding such payments,

2. whether written guidance is available to relevant

155. Richar Alderman, Director, Serious Fraud Office, Hosted by Salans, Managing corruption risk in the real world, (Apr. 7, 2011) (emphasis added) available at http://www.sfo.gov.uk/about-us/our-views/director\%27s-speeches/speeches-2011/salans---briberyact-2010.aspx.

156. See 15 U.S.C. $\S \S 78 \mathrm{dd}-1$ (b), 78dd-2(b), 78dd-3(b); see infra note 170.

157. See e.g., Cheryl A. Krause \& Elisa T. Wiygul, FCPA Compliance: The Vanishing "Facilitating Payments" Exception?, FIN. FRAUD L. REP., 730, 730-31 (2010). available at http://www.dechert.com/files/Publication/53b317c3-d963-4ca6-9cbc-23cc76fa60d2/Presentation/ PublicationAttachment/12e5a22a-daea-4d72-adc1-3048bfa33fb2/FCPA\%20Compliance.pdf.

158. Infra note 175.

159. Infra note 174 .

160. Guidance, supra note 65 , at $\lceil 45$. 
employees as to the procedure they should follow when asked to make such payments,

3. whether such procedures are being followed by employees,

4. if there is evidence that all such payments are being recorded by the company,

5. if there is evidence that proper action (collective or otherwise) is being taken to inform the appropriate authorities in the countries concerned that such payments are being demanded,

6. whether the company is taking what practical steps it can to curtail the making of such payments. ${ }^{161}$

If the SFO is satisfied with the answers to these questions, the company, while still in technical breach of the law, will not be prosecuted for making facilitation payments. As noted, there is no current guidance, learning, or lore on what are the "practical steps" demanded by item 6 in this list to eliminate such a ubiquitous practice. Even if such practical steps as might be created did satisfy prosecutors at the SFO, this is far from a "safe harbor." Prosecutors change, especially recently at the SFO. ${ }^{162}$ Perhaps more important, business involves economic risk taking. Adding regulatory and legal uncertainty to these economic risks must, at the margin, hurt business.

Moreover, the United Kingdom's past treatment of facilitation payments demonstrates that it has not actually taken the hardline approach that it is now propounding. While it is technically true that facilitation or "grease" payments have always been prohibited under English law, it is equally true that no prosecutions were ever attempted for such payments made overseas. Furthermore, notwithstanding the Justice Ministry's citing of the 2009 OECD "Recommendation," the OECD Convention does not require that these payments be outlawed. Commentary 9 to the OECD Convention as originally published provided:

Small "facilitation" payments do not constitute payments made "to obtain or retain business or other improper advantage" within the meaning of paragraph 1 and,

161. See Barry Viton \& Richard Kovalevsky Q.C., Facilitation Payments, THEBRIBERYACT.COM, http://thebriberyact.com/facilitation-payments/ (last visited Mar. 4, 2013).

162. The following senior officials at the SFO have recently left the SFO: Kathleen Harris, former Head of SFO Fraud Business Group, now at Arnold \& Porter-London; Charles Montieth, SFO's former Head of Assurance, now at White \& Case; Robert Amaee, now at Covington \& Burling; Helen Garlick, former SFO assistant director, now at Fulcrum Chambers; Richard Alderman, former Head of SFO 2008-2012, now retired. 
accordingly, are also not an offence. Such payments, which, in some countries, are made to induce public officials to perform their functions, such as issuing licenses or permits, are generally illegal in the foreign country concerned. Other countries can and should address this corrosive phenomenon by such means as support for programmes of good governance. However, criminalisation by other countries does not seem a practical or effective complementary action. ${ }^{163}$

While this statement criticized facilitation payments, calling them a "corrosive phenomenon," neither this revised statement nor the Convention calls for their criminalization. Moreover, the revised 2009 language of Commentary 9 cited in the Guidance merely states that such payments are "generally illegal in the foreign country concerned but are tolerated for many reasons when made to induce public officials to perform their official functions," and, like the original commentary, states that "criminalisation by other countries does not seem a practical or effective complementary action." 164

In fact, the OECD Council's most recent stance on facilitation payments, set forth in a formal Recommendation in November 2009, ${ }^{165}$ contained only the following:

VI. [The Council] RECOMMENDS, in view of the corrosive effect of small facilitation payments, particularly on sustainable economic development and the rule of law that Member countries should:

i) undertake to periodically review their policies and approach on small facilitation payments in order to effectively combat the phenomenon;

ii) encourage companies to prohibit or discourage the use of small facilitation payments in internal company controls, ethics and compliance programmes or measures, recognising that such payments are generally illegal in the countries where they are made, and must in all

163. Organisation for Economic Co-operation and Development, Convention on Combating Bribery of Foreign Public Officials in International Business Transactions and Related Documents, OECD.ORG, 15 (2011), http://www.oecd.org/dataoecd/4/18/38028044.pdf. See also Jon Jordan, The OECD's Call for an End to "Corrosive" Facilitation Payments and the International Focus on the Facilitation Payments Exception Under the Foreign Corrupt Practices Act, 13 U. PA. J. Bus. L. 881, 896-97 (2011).

164. OECD, supra note 156 , at 15 . See also Jordan, supra note 156 , at 896-902.

165. OECD, supra note 156, at 22. 
cases be accurately accounted for in such companies' books and financial records. ${ }^{166}$

By flatly calling for the end of facilitation payments overseas and for criminalizing those who fail to prevent them, Parliament has gone well beyond the OECD's call to "encourage companies to prohibit or discourage" facilitation payments. Where the OECD has urged companies to take steps to "prohibit or discourage the use of small facilitation payments," Parliament has, we believe, consciously taken the politically expedient, but completely unrealistic, position of making it a crime to make such payments. Bribery and corruption have been part of human society for thousands of years. ${ }^{167}$ For certain, more than 30 years of experience with the FCPA has not led to any perceptible reduction in the amount of corruption in international business.

Moreover, the SFO Senior Staff has "stated that a company's policies should address the possibility of such payments being made, incorporating the relevant [Attorney General] and Ministry of Justice Guidance in this regard." "168 The Staff explained that the SFO takes a sympathetic approach toward "emergency facilitation payments," and offered an example: a visitor to a foreign country requires an inoculation and is offered the choice of paying $\$ 5$ to be inoculated with a clean needle, or not paying and being inoculated with a used needle. They stated that in this case, prosecution is unlikely if the payment is made. ${ }^{169}$ Thus, the SFO Staff has also acknowledged the difficulty with an outright prohibition on facilitation payments.

Incongruously, the Ministry of Justice has also conceded in the Guidance that eradicating facilitation payments will be no small feat:

The [UK] Government does, however, recognise the problems that commercial organisations face in some parts of the world and in certain sectors. The eradication of facilitation payments is recognised at the national and

166. Id. (emphasis added).

167. Consider this quotation from 2500 years ago: "Just as it is impossible not to taste the honey (or the poison) that finds itself at the tip of the tongue, so it is impossible for a government servant not to eat up, at least, a bit of the king's revenue. Just as fish moving under water cannot possibly be found out either as drinking or not drinking water, so government servants employed in the government work cannot be found out (while) taking money for themselves." Pranab Bardhan, Corruption and Development: A Review of Issues, 35 J. ECON. LITERATURE 1320, 1320 (1997) (citing R.P. KANGLE, INTERPRETING KAUTILIYA, ARTHASASTRA, 4th Century B.C., (1979)). This is further illustrated in Bruce W. Bean, Hyperbole, Hypocrisy and Hubris in the AidCorruption Dialog, 41 GEO. J. INT'L L. 781, 786 (2010).

168. Dunn Article, supra note 108, at 2.

169. Id. 
international level is a long term objective that will require economic and social progress and sustained commitment to the rule of law in those parts of the world where the problem is most prevalent. ${ }^{170}$

The Bribery Act makes it a crime to make facilitation payments even as the government makes clear that eliminating the need to make them cannot be accomplished, except, perhaps in the "long term." Why did Parliament take such a position? There are several possible contributing factors. Parliament was doubtless sensitive to the years of criticism from the OECD Working Group and from international NGOs like Transparency International. Domestic groups, such as the two that immediately challenged the termination of the SFO's investigation of BAE in December 2006, The Cornerhouse and the Campaign Against the Arms Trade, ${ }^{171}$ were also successful in generating media interest in the failure of Parliament to comply with the need for legislation called for by the OECD Convention. There was also the wish to restore the United Kindoms's reputation after the international media excoriated UK hypocrisy over the BAE scandal. ${ }^{172}$ An additional factor was the contemporaneous "Rotten Parliament" scandal directly implicating almost 400 members of Parliament in inappropriate or fraudulent claims for reimbursement of allowances and expenses at precisely the moment Parliament was contemplating finally complying with the requirements of the OECD Convention. ${ }^{173}$ In its embarrassment over

170. GUIDANCE, supra note $65, \uparrow 46$.

171. See supra text accompanying note 47 ; see e.g., News Release, CAAT and Comer House confident as appeal begins in Lords, CONTROLBAE.ORG..uk (Jul. 6, 2008) available at http://www.controlbae.org.uk/press/release2008-07-06.php .

172. A hint of this may be detected in the following statement from Jack Straw, Minister of Justice, which was included in the Foreword to the March 2009 draft Bribery Bill that had been reported on by the joint Committee in July 2009: "The United Kingdom is recognised as one of the least comupt countries in the world. We are proud of the high ethical standards we uphold in public and commercial life. But we must not rest on our laurels. Bribery is by its very nature insidious; if it is not kept in check it can have potentially devastating consequences." (emphasis added).

173. "Briefly, in 2009, London's Daily Telegraph ran a series of articles exposing a major breach of trust by more than half the Members of Parliament. Parliament fought to keep the information confidential but the Telegraph received leaked computer disks and published detailed expense filings of British members of Parliament. The British public was outraged to learn that they, the taxpayers, were, in effect, funding as reimbursable Parliamentary expenses everything from gardening and tennis court repairs to flat-screen TVs and even pornographic videos . ..." Paul Hechinger, Infamous British Political Scandals: Expenses and the "Rotten Parliament," BBC AMERICA (Jan. 11, 2012), http://www.bbcamerica.com/anglophenia/2012/01/infamous-british-political-scandals-expensesand-the- $\% \mathrm{E} 2 \% 80 \% 98$ rotten-parliament $\% \mathrm{E} 2 \% 80 \% 99 /$ (Of the 392 Members of parliament implicated, some had used public funds to pay mortgages on their relatives' homes. The disclosures resulted in lengthy investigations, many resignations, the implementation of new 
both the BAE and Rotten Parliament scandals, Parliament enacted an unusually draconian Bribery Act.

What is a non-UK company expected to do to comply with the Act? If the choices are either knowingly violate the Bribery Act or stop doing business "in those parts of the world" where bribery is common, these are not wonderful alternatives. It will be more likely that a non-UK business simply avoid all contact with London and the United Kingdom, a surely unintended consequence of Parliament's much delayed enactment of the Bribery Act. The dilemma facing non-UK companies involved in international business is stark, as illustrated by an example from the United States. A Board of Directors has a clear obligation under Delaware law to establish procedures designed to insure that its company does not violate "positive law." 174 It is plainly illegal under the Bribery Act to make facilitation payments, except in "emergencies," such as threats involving "loss of life, limb or liberty," where prosecution is unlikely. ${ }^{175}$ But if the price were $\$ 1000$, is prosecution still "unlikely?" Is "unlikely" comfort enough for the Board? And what policy should a Board of Directors of a company that perhaps does some small "part" of its business in the UK establish given the clear direction from Delaware courts that the Board's fiduciary obligation is to make certain company employees do not intentionally violate the law?

It is clear that the so-called "continued outlawing" of facilitation payments under the Bribery Act is one of the most problematic aspects of the law. Given the extreme position the SFO has taken with respect to the jurisdictional reach of the Act, purporting to ensnare all organizations that have some connection with the United Kingdom, one can perhaps be forgiven for suggesting that Parliament, knowing that US-based companies are permitted to make facilitation payments and observing that the

expense rules and accounting, and enormous embarrassment. The scandal of the "Rotten Parliament," as it came to be called, also resulted in criminal charges, convictions, and prison sentences. Id.). See also British Parliament Expense Abuses, NYTIMES.COM (Feb. 5, 2010), http://topics.nytimes.com/topics/reference/timestopics/organizations/b/british_parliament/ expense_abuses/index.html.

174. The Delaware Supreme Court established the test for "director oversight," which contemplates that a director must act in good faith in In re Walt Disney Co. Derivative Litigation, by adopting the test set forth in the lower court opinion. 906 A.2d 27 (Del. 2006) ("The good faith required of a corporate fiduciary includes not simply the duties of care and loyalty...but all actions required by a true faithfulness and devotion to the interests of the corporation and its shareholders. A failure to act in good faith may be shown, for instance, where the fiduciary intentionally acts with a purpose other than that of advancing the best interests of the corporation, where the fiduciary acts with the intent to violate applicable positive law, or where the fiduciary intentionally fails to act in the face of a known duty to act, demonstrating a conscious disregard for his duties." Id. at 67 (emphasis added).).

175. "It is recognised that there are circumstances in which individuals are left with no alternative but to make payments in order to protect against loss of life, limb or liberty. The common law defence of duress is very likely to be available in such circumstances." GUIDANCE, supra note 65, ๆ 48 . 
overwhelming majority of multinational enterprises investigated and fined by US officials under the FCPA in recent years have been non-US firms deliberately targeted relevant commercial organizations established in the United States. ${ }^{176}$ Such targeting perhaps satisfied a goal of some involved in preparing the Bribery Act of reestablishing the United Kingdom as a global leader in fighting corruption, following the embarrassment of the BAE and Rotten Parliament scandals. ${ }^{17}$

\section{Hospitality Payments}

In addition to the intractable problem posed by small facilitation payments for companies squarely within the scope of the Bribery Act, and perhaps those doing only very occasional business in the United Kingdom, the Bribery Act presents further issues for business entertainment costs, known in the Act as "hospitality payments." With regard to these payments, the Ministry of Justice has explained:

Bona fide hospitality and promotional, or other business expenditure which seeks to improve the image of a commercial organisation, better to present products and services, or establish cordial relations, is recognised as an established and important part of doing business and it is not the intention of the Act to criminalise such behaviour. $^{178}$

The Guidance states that for an entertainment expense to amount to a bribe, there must be "an intention for a financial or other advantage to influence the official in his or her official role and thereby secure business or a business advantage.,"179 The Guidance further restates its familiar refrain: "In many cases, ... the question as to whether such a connection [between the advantage offered and the intention to secure a business advantage] can be established will depend on the totality of the evidence which takes into account all of the surrounding circumstances." ${ }^{180}$ A determination based upon such a "totality of the evidence" can only be authoritatively made by a court.

The examples offered in the Guidance demonstrate that whether a

176. See, e.g., Leslie Wayne, Foreign Firms Most Affected by a U.S. Law Barring Bribes, N.Y. TIMES, (Sept. 3, 2012), http://www.nytimes.com/2012/09/04/business/global/briberysettlements-under-us-law-are-mostly-with-foreign-countries.html?_r=2\&ref=business.

177. See JOINT COMMITTEE ON THE DRAFT BRIBERY BILL, DRAFT BRIBERY BILL, 2008-9, H.C. 430-I \& H.L. 115-I, ๆ 88 (U.K.).

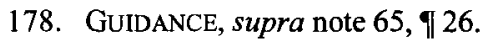

179. GUIDANCE, supra note $65, \uparrow 27$.

180. Id. ๆ 28. 
hospitality payment would be found to be illegal depends heavily on context. ${ }^{181}$ The Guidance provides that while expenditure levels are not the only consideration in determining whether a Section 6 offense, bribery of a foreign public official, has been committed:

[I]n the absence of any further evidence demonstrating the required connection, it is unlikely, for example, that incidental provision of a routine business courtesy will raise the inference that it was intended to have a direct impact on decision making, particularly where such hospitality is commensurate with the reasonable and proportionate norms for the particular industry; e.g. the provision of airport to hotel transfer services to facilitate an on-site visit, or dining and tickets to an event. ${ }^{182}$

However, the Guidance once again proves itself to be virtually useless to the many companies actually doing business while aware of their obligation to comply with the Bribery Act. Most companies operating internationally now have "compliance officers" whose sole function is to instruct their employers as to what conduct is permitted under the Act. Can a company compliance officer function effectively when her best option is to wait to see whether the SFO prosecutes hospitality?

Indeed, the UK government spokesman at the time of Parliament's consideration of the Bribery Act acknowledged, in January 2010, the scope of the problem with criminalizing hospitality payments:

We recognise that corporate hospitality is an accepted part of modern business practice and the Government is not seeking to penalize expenditure on corporate hospitality for legitimate commercial purposes. But lavish corporate hospitality can also be used as a bribe to secure advantages and the offences in the Bill must therefore be capable of penalising those who use it for such purposes. ... Corporate hospitality would...trigger the offence only where it was proved that the person offering the hospitality intended the recipient to be influenced to act improperly. ${ }^{183}$

One commentator nicely frames this gray area: "Fixing the appropriate borderline between generous hospitality ... and the criminal giving and

181. Id. ๆ 31.

182. Id. $₫ 30$.

183. Letter from Lord Tunnicliffe to Lord Henley of the House of Lords, (Jan. 14, 2010), available at http://www.justice.gov.UK/publications/docs/letter-lord-henley-corporatehospitality.pdf.UK 
taking of unconscionable, material advantages on the other, is not easy to capture in language suitable for forensic use." 184 The accuracy of this statement is plain. While conceding the difficulty of the distinction between "lavish" and "legitimate" forms of hospitality, Parliament, the Ministry of Justice, and the SFO could have done better.

The FCPA includes an affirmative defense ${ }^{185}$ that is somewhat more descriptive:

It shall be an affirmative defense to actions under subsection (a) or (g) of this section that--

(2) the payment, gift, offer, or promise of anything of value that was made, was a reasonable and bona fide expenditure, such as travel and lodging expenses, incurred by or on behalf of a foreign official, party, party official, or candidate and was directly related to--

(A) the promotion, demonstration, or explanation of products or services; or

(B) the execution or performance of a contract with a foreign government or agency thereof. ${ }^{186}$

Thus, the FCPA has a somewhat more realistic and flexible approach to the criminalization of hospitality payments than does the Bribery Act. However, Parliament did not have the foresight, or possibly the intent, to offer a similar defense for companies that are subject to the Bribery Act's provisions; instead, companies can rely only on the Guidance's admonition that each situation involving hospitality expenditures will be fact-specific.

Surely the business community needs and deserves more from Parliament's mandated "guidance" than to merely hope that the reputation damage that an SFO investigation would engender and the huge expense of litigation would not be triggered each time a business lunch is recorded on its books. Unfortunately, this is one more example of the Bribery Act's unjust mandates, and only time will tell how such cases will actually be prosecuted it is not likely that many companies will remain unscathed for what are most likely legitimate business expenditures. In keeping with this theme, in the next section we discuss the lack of due process inherent in the

184. G. R. Sullivan, Reforming Bribery: Law Commission Consultation Paper 185- (2), Reforming the Law of Bribery (LCCP No. 185): Bribery Outside England and Wales: Corporate Liability; Defences; Consent to Prosecution, Crim. L, Rev. 687-701 (2008).

185. A second affirmative defense, but one of no real practical use, is to establish that "the payment, gift, offer, or promise of anything of value that was made, was lawful under the written laws and regulations of the foreign official's, political party's, party official's, or candidate's country." 15 U.S.C. $\S \S 78 d d-1(c)(1), 78 d d-2(c)(1), 78 d d-3(c)(1)(2012)$.

186. 15 U.S.C. $\$ 78 \mathrm{dd}-1$ (c). 
Act's criminalizing failure to prevent bribery.

\section{B. Comment on Strict Liability, Due Process, and ECHR Article 6(2)}

The total absence of due process in the Section 7 strict liability crime is clear.

When in 2008 the Law Commission was directed for the second time in ten years to review existing laws on bribery, the Commission was specifically requested to draft a bill which would include provisions that "are fair and non-discriminatory in accordance with the European Convention on Human Rights (ECHR) and the Human Rights Act 1998." 187

Article 6(2) of the European Convention provides that "[e]veryone charged with a criminal offense shall be presumed innocent until proved guilty according to law." ${ }^{\text {"188 }}$ Article 6 of the UK Human Rights Act, entitled Right to a Fair Trial, similarly provides: "[i]f it is a criminal charge you are presumed innocent until proved guilty according to law and have certain guaranteed rights to defend yourself." ${ }^{189}$ The strict liability for a commercial organization under Section 7 of the Bribery Act contravenes these mandates.

Taking heed of its mandate to prepare a draft that complied with the ECHR and the Human Rights Act and having taken specific advice from UK legal experts on this point, the Law Commission's draft bill included a failure to prevent bribery provision, but one which did not violate Article 6(2). ${ }^{190}$ This provision differed in two major respects from the provision in the final Bribery Act. The corporate failure to prevent bribery offense was limited to businesses organized in England or Wales and thus was well within traditional notions of territorial jurisdiction. Second, the bribe triggering the charge of failing to prevent a bribe had to result from negligence of a person responsible for preventing such bribe. ${ }^{191}$ Six months later, in March 2009, the Ministry of Justice, having reviewed the Law Commission's report, submitted its draft bill to Parliament. ${ }^{192}$ The Ministry of Justice draft retained the negligence element ${ }^{193}$ but extended the law's jurisdictional grasp by not limiting its jurisdiction to businesses organized in England and Wales. Rather, the draft submitted to Parliamentary review

187. See LaW COMmission, CONSUltation PAPER, supra note 45, at p. 14.

188. EUROPEAN CONVENTION ON HUMAN RIGHTS, Art. 6(2), Nov. 4, 1950, 3213 U.N.T.S. 221, available at http://www.hri.org/docs/ECHR50.html\#Convention.

189. Human Rights Act, 1998, c. 42, sch. 1 available at http://www.legislation.gov.uk/ ukpga/1998/42/schedule/1/part///chapter/5/data.pdf.

190. LAW COMMISSION, CONSUltation PAPER, supra note 44, at pp. 164-65.

191. Id. at 164 .

192. Ministry OF Justice, Bribery ACt Draft Legislation, 2009, Cm. 7570, at p. 1 (U.K.) available at $\mathrm{http}: / / \mathrm{www} .0 f f i c i a l-d o c u m e n t s . g o v . u k / d o c u m e n t / \mathrm{cm} 75 / 7570 / 7570$.pdf.

193. Id. §5(1)(c). 
made the offense applicable to any business "which carries on a business, or part of a business, in England, Wales or Northern Ireland."194

During Parliament's consideration of the government draft, certain non-governmental organizations and individuals proposed to eliminate the negligence element, arguing that this provision offered only a "narrow and complex solution to a pressing problem." 195 Professor Jeremy Horder, the Law Commission's expert on criminal law, disagreed. As stated in the Report of the Joint Committee that reviewed the government's draft law:

Professor Horder acknowledged the greater simplicity of dropping negligence as an element of the offence, but he did not believe that it would be fair to convict a company for the criminal act of its employee or agent without requiring the prosecution to prove that the company was itself at fault. He distinguished bribery as a "step up" in seriousness from any existing strict liability offence under health and safety or other legislation:

[It] is very different from attributing causal consequences, like earwigs in tins or deaths occurring on ships or wherever it may be, to a company .... Y You can only fairly, in my view, connect a deliberate act of bribery by an employee or agent to a company via the company's own fault, if I could put it that way, or here we have got it as 'a responsible person or number of persons.'. ${ }^{196}$

The directors of both the SFO and the Crown Prosecution Service testified before Parliament's Joint Committee and agreed with Professor Horder as to the unfairness of eliminating the negligence element from the Section 7 crime. ${ }^{197}$ Parliament ignored the opinions of the Law Commission's expert, Professor Horder, and legal conclusions of those responsible for enforcing UK law and eliminated the negligence element from the Section crime of failing to prevent bribery. Parliament attempted to justify its approach by citing the "everyone else is doing it" defense, finding that strict liability would not be unfair "given the parallel with the approach taken in other leading countries." 198 The Joint Committee did

194. Id. $\S 5(7)$.

195. JOINT COMMITTEE ON THE DRAFT BRIBERY BILL, DRAFT BRIBERY BILL, 2008-9, H.C. 430-I \& H.L. 115-I, ๆ 76 (U.K.), citing BRIBERY: CORPORATE LIABILITY UNDER THE DRAFT BILL 2009, CRIM. L. REV. 479 (2009).

196. Id. ๆ 83.

197. Id.

198. Id. ๆ 9. The other leading countries to which Parliament referred were the United 
receive testimony on enforcement of anti-bribery laws in other jurisdictions, but no consideration was given to the unique provision in the bill applying it to businesses not organized in the United Kingdom. This strict liability offense will surely be tested in court as a violation of the ECHR's requirement of the presumption of innocence standard.

\section{CONCLUSION}

In this article we have summarized the extended history that led to the enactment of the UK Bribery Act 2010, the UK legislation required to comply with the OECD Convention on Combating Bribery of Foreign Public Officials in International Business Transactions. After signing the OECD Convention, the British government took the position that its existing domestic anti-bribery legislation satisfied this requirement. However, others disagreed, and the OECD Working Group established to monitor compliance consistently found UK compliance to be lacking. The UK government set about reforming its existing corruption legislation, based on the recommendation of the Nolan Report and the Parliamentary Select Committee on Standards in Public Life that reform was necessary. However, the "reform" process consisted of more than a decade of debating, consulting, and infighting as various government bodies dragged their feet on agreeing on a final version of a new corruption law, specifically targeting bribery. When the Bribery Act was finally enacted, more than thirty years after the FCPA went into effect, the result, as we have shown, was, in a word, disappointing, despite Parliament's apparent goal of ending bribery in the United Kingdom and everywhere.

The offenses of active and passive bribery cover a wide spectrum of conduct and would benefit from more clear-cut, definitive guidance from the Ministry of Justice. Moreover, various terms in the Bribery Act emphasize the overly broad jurisdictional reach of the Act, which will surely have unintended consequences for companies abroad. For example, as we have discussed regarding "relevant function or activity," the acting party is guilty even where the relevant function or activity is carried out abroad. The activity need not have any connection to the United Kingdom, and the measure of what is "improper" is determined by UK standards, not by those of the foreign country where the bribing occurs. Furthermore, a relevant function or activity is performed improperly if it is performed in breach of a relevant expectation, or the failure to perform is a breach of a relevant expectation. However, the breach of a relevant expectation follows a reasonableness test, based only on what is considered "reasonable" in the United Kingdom. Likewise, an offense under Section 6, pertaining to bribery of a foreign public official, has no jurisdictional limit: a foreign public official includes anyone, whether elected or appointed, who holds a 
legislative, administrative, or judicial position of any kind of a country or territory outside the United Kingdom.

Most importantly, we have shown in particular that the strict liability corporate offense of failure to prevent bribery is an unprecedented attempt to govern international business transactions with only the vaguest connection to the United Kingdom. The Act also broadens the definition of "bribe" to include the types of small facilitation payments regularly found to be essential when traveling or operating in some developing nations. Furthermore, Parliament has permitted only a single defense to its strict crime of failing to prevent a bribe. Perhaps recognizing the absurd nature of the "adequate procedures" defense, Parliament demanded that the government publish guidance explaining how a business could comply with the "Alice in Wonderland" defense of proving its procedures were adequate despite their failure. Clearly, the Ministry of Justice's Guidance fails to provide meaningful guidance on this crucial question. Finally, we noted that in enacting Section 7, Parliament ignored the due process standard established by the ECHR and the United Kingdom's own Human Rights Act.

The Bribery Act 2010 is the disappointing result of years of delay and deliberation on the part of both the government and Parliament. The hardships that companies now face in attempting to comply with the Act are just beginning. The contours of the Bribery Act will be fully known only as the judiciary construes this law. The unintended consequences of Parliament's apparent need to enact what can only be called a truly draconian anti-bribery law in order to overcome the embarrassment of the government's role in the BAE scandal, the oft-criticized dozen years of procrastination before the Bribery Act was passed, and its own Allowances and Expenses scandal will be forthcoming for years. 
